\title{
Explanation of the Managerial Competencies of Healthcare Staff to Discounting the Number of Martyrs and Veterans in the Iran-Iraq War: A Qualitative Study
}

\section{ART I C L E INF O}

\section{Article Type}

Qualitative Study

\section{Authors}

Farsi Z. ${ }^{1} P h D$,

Rajai N.*2 $M S c$

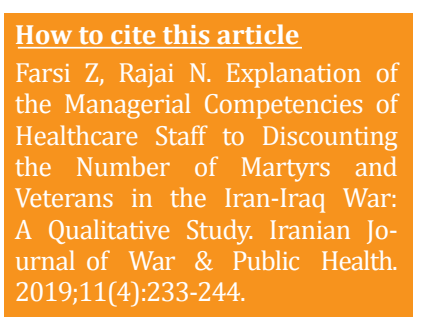

\section{A B S T R A C T}

Aims Nowadays, the use of the experiences and lessons learned by staff, including health care providers, has been emphasized as a key strategy in knowledge management. The aim of this study was to explain the managerial competencies of healthcare staff to discount the number of martyrs and injuries of injured people (veterans) in the Iran-Iraq war.

Contributors \& Methods This qualitative study was carried out using the conventional content analysis method in 2018-2019. 119 written narratives of 101 healthcare staff, in the area of providing therapeutic care to martyrs and veterans, were collected and simultaneously analyzed. Principles of qualitative data analysis were used for data analysis.

Findings The analysis of data led to the emergence of three main themes of management and leadership, providing resources and executive management. The sub-themes of management and leadership including planning, organizing and coordinating, decision-making skills and risk appetite, and management stability. Sub-theme of providing resources including providing human resources and providing physical resources. Sub-theme of executive management included readiness, protective and security measures, carelessness and negligence and registration of documents.

Conclusion The managerial competencies of healthcare providers include management and leadership providing resources and executive management, which have been used to discount the number of martyrs and veterans in the Iran-Iraq war.

Keywords Casualties; Healthcare Staff; Management; Injured; Veterans; War
${ }^{1}$ Research \& Community Health Department, Nursing Faculty, Aja University of Medical Sciences, Tehran, Iran

${ }^{2}$ Maternal-Infant Health Department, Nursing Faculty, Aja University of Medical Sciences, Tehran, Iran

\section{*Correspondence}

Address: Nursing Faculty, Aja University of Medical Sciences, Kaj Street, Shariati Street, Tehran, Iran. Postal Code: 1613916151

Phone: +98 (21) 77500404

Fax: +98 (21) 77601533

n.rajai22@yahoo.com

\section{Article History}

Received: May 6, 2019

Accepted: September 30, 2019

ePublished: December 21, 2019

\section{CIT A T I O N L IN KS}

\begin{abstract}
[1] Mortality and injuries among Iranians in Iran-Iraq ... [2] Years of life lost among Iranian people killed in ... [3] Roy's adaptation model-guided education on ... [4] Development of adaptation questionnaire using Roy's adaptation ... [5] Effect of Roy's adaptation modelguided education ... [6] Exploring coping strategies of healthcare providers with tension sources ... [7] The evaluation of application of coordination based disaster response ... [8] Nurses' perceptions of care during wartime: a qualitative ... [9] Pain and suffering: Experiences of health care professionals in ... [10] Military nurses and combat-wounded patients: a qualitative ... [11] Experiences of the civilian Iranian operating room nurses: a historical survey ... [12] Combat stressors and posttraumatic stress in deployed ... [13] Knowledge, attitude, and performance of nurses' crisis management in natural ... [14] System of educational and qualification-based ... [15] The effects of imposed war on ... [16] Professionalism of healthcare jobs ... [17] Military nurses' experiences returning ... [18] Exposure to war traumatic experiences, post-traumatic ... [19] Lessons learned and advice from Vietnam ... [20] Containing trauma: nursing work in The First ... [21] From margins to center: an oral history of the ... [22] The wartime experience of civilian nurses in ... [23] Rescue and transportation experiences of medical department ... [24] Pharmaceutical and medical experiences Sepah in Valfajr ... [25] A review of medical experiences of Sepah in Holy Defense ... [26] Lessons learned from war: a comprehensive review of the ... [27] Field hospitals in Iraq-Iran ... [28] Rescue and transportation brigade in Iraqi imposed ... [29] Qualitative research ... [30] Criteria of validity and reliability in qualitative ... [31] Nurses' requirements for relief and casualty support ... [32] First aid and transportation course contents based on ... [33] Studying the managers' viewpoint of East Azerbaijan provinces ... [34] Spiritual experiences and memories of healthcare personnel ... [35] Death on the battlefield and the role of first ... [36] Assessment of triage and transportation in Bam earthquake ... [37] Army nursing practice challenges in humanitarian ... [38] The military nurse in Vietnam: stress and ... [39] Women at war: The crucible of ... [40] Sexual harassment and assault in the ...
\end{abstract}


بهواسطه عوارض جراحات جنكى يا مينهاى زمينى كاشتهشه يا

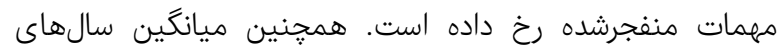

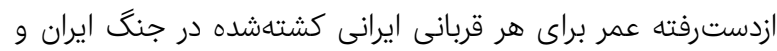

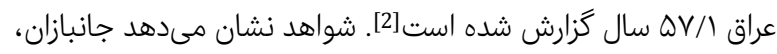

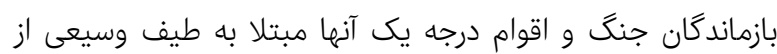

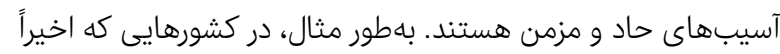

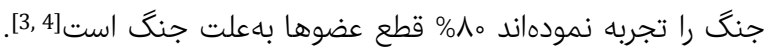

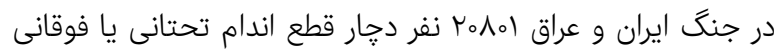

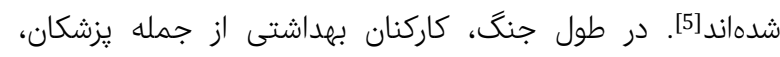

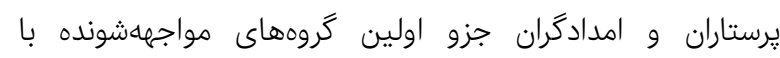

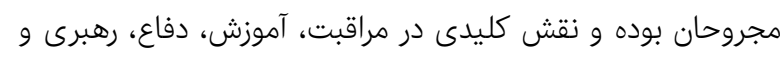

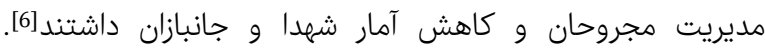

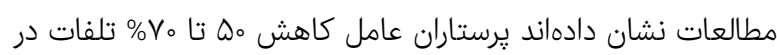

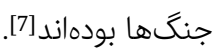

ماهيت ارايه مراقبت در طول جنَّ نسبت به شرايط عادى بسيار

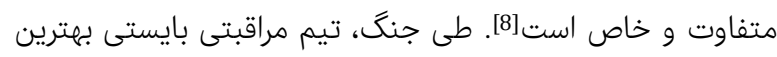

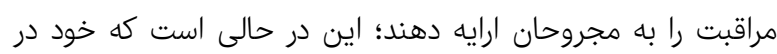

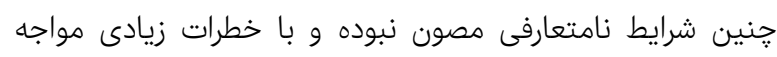

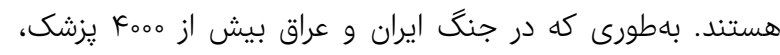

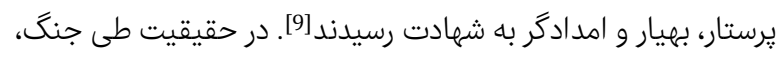

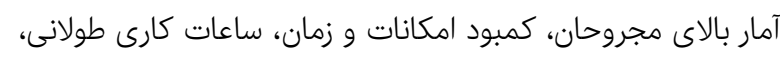

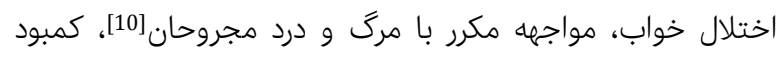

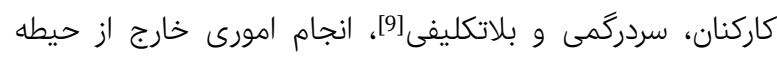

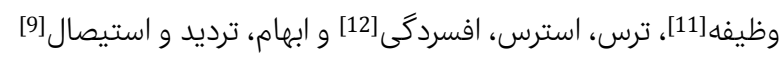

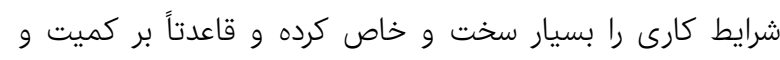

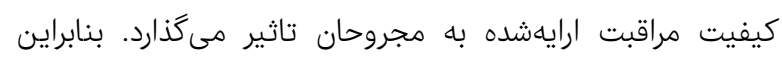

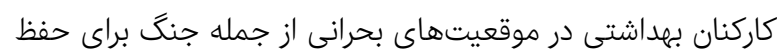

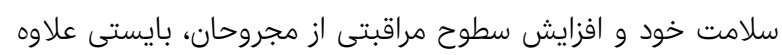

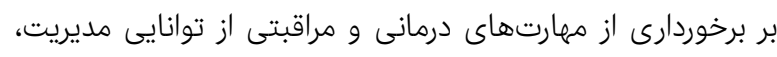

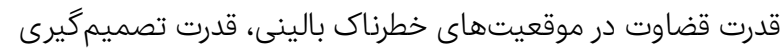

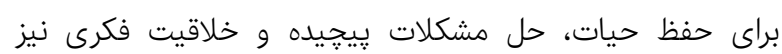

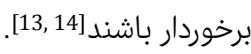

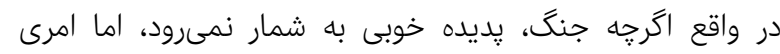

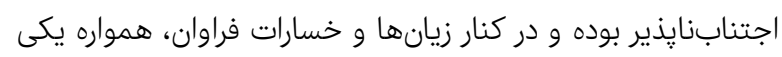

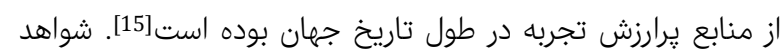

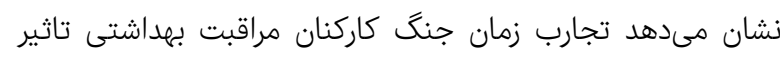

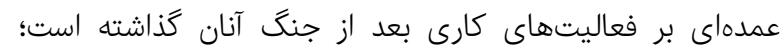

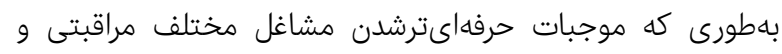

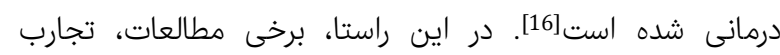

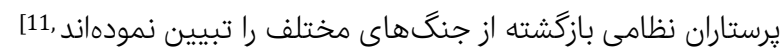

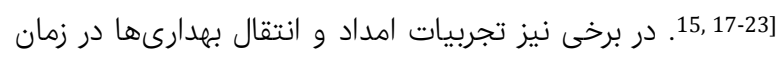

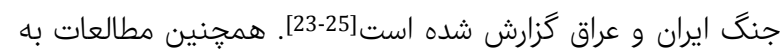

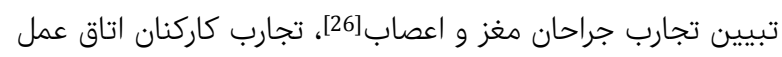

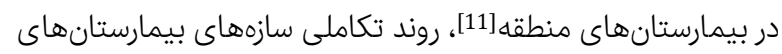

تبيين صلاحيتهاى مديريتى كاركنان بهداشت و

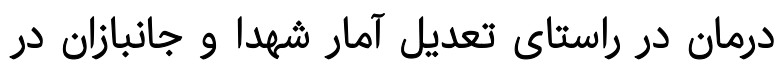

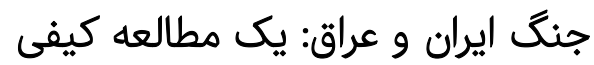

زهرا فارسى PhD

كروه بهداشت جامعه، دانشكده يرستارى، دانشكاه علوم يزشكى آجا، تهران، ايران

MSc ناهيد رجائى

كروه بهداشت مادران و نوزادان، دانشكده برستارى، دانشكاه علوم يزشكى آجا، تهران، ايران

جكيده اهداف: امروزه، استفاده از تجارب و درسآموختههاى كاركنان از جمله مراقبان

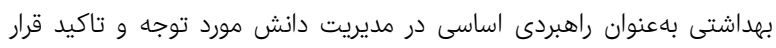

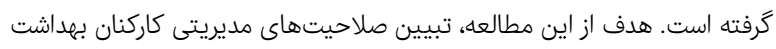

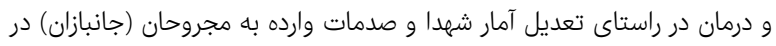
جنگ ايران و عراق بودان

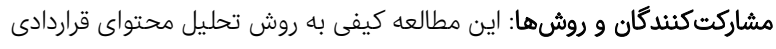

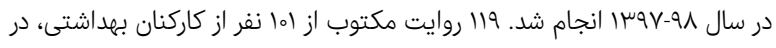

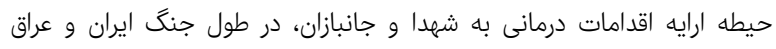

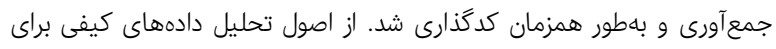
تحليل دادهها استفاده شد.

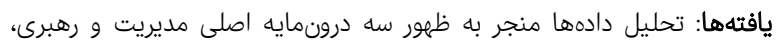

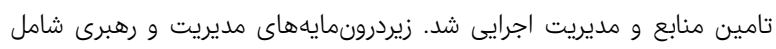

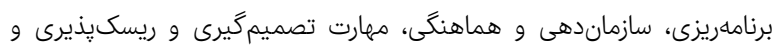

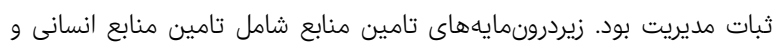

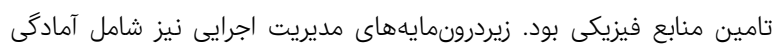

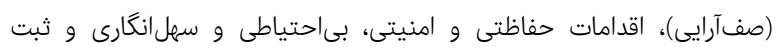

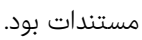
نتيجه گيرى: صلاحيتهاى مديريتى مراقبان بهداشتى شامل مديريت و رهبرى،

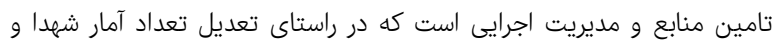

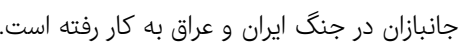

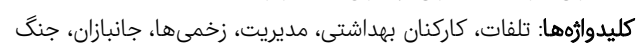

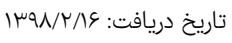

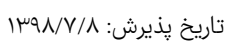

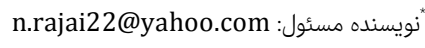

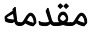

جنگ ها بهعنوان نوعى بحران انسانساخت، در طول عمر بشر هميشه

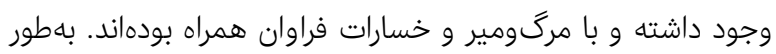

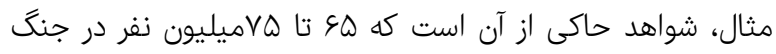

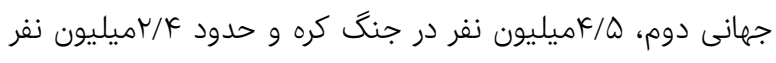

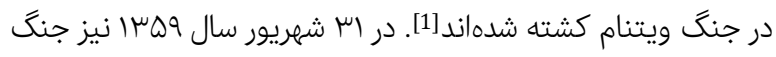

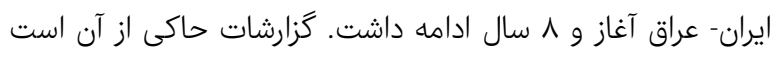

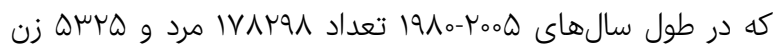

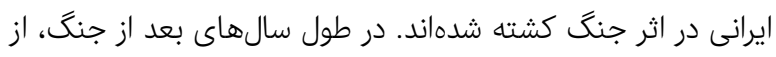

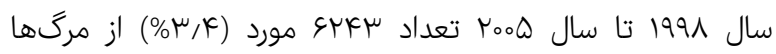




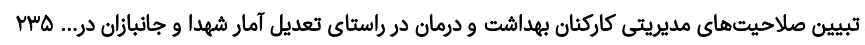

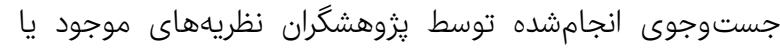

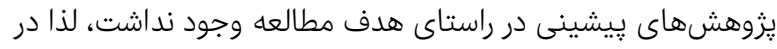

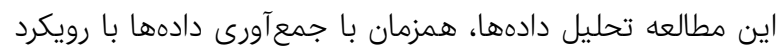
تحليل محتواى كيفى قراردادى انجام شد. تحليل محتواى قراردادى دهان

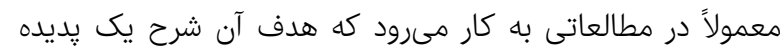

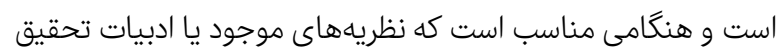
درباره يديده مورد مطالعه محدود باشد [29].

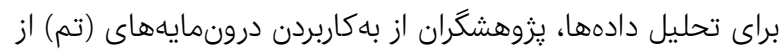

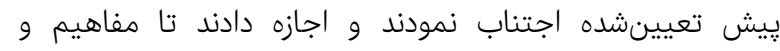

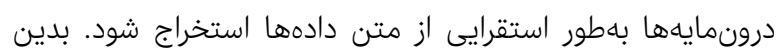

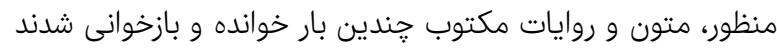

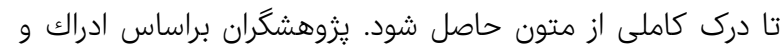

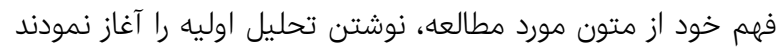

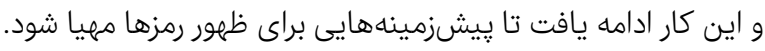

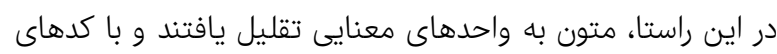

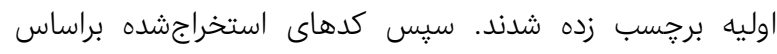
شباهتها و تفاوتها مقايسه و به درونمايهها و زيردرونمايهها

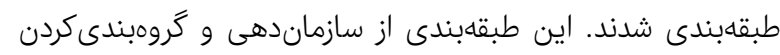

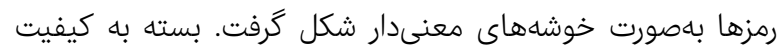

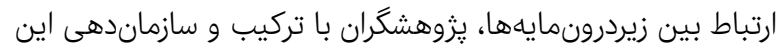

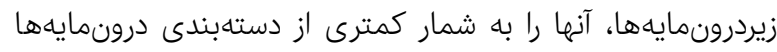

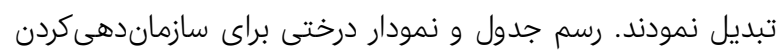

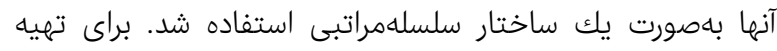

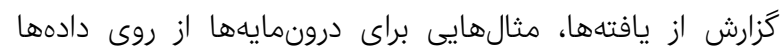

مشخص شد. لازم به ذكر است كه در اين روند، هم تحليل محتواى بارز و هم

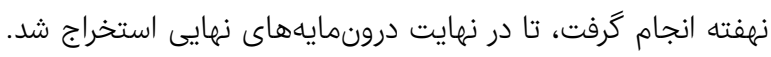
همجنين "تحليل مقايسه مداوم" كه از رويكردهاى اصلى تحليل

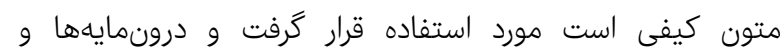

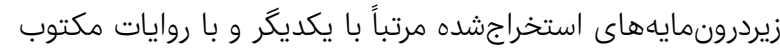

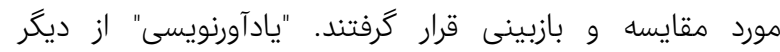

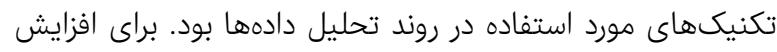

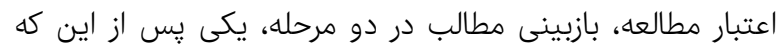

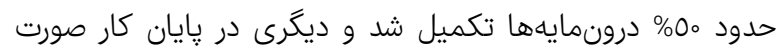

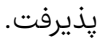
كوبا و لينكلن، "قابليت اعتماد" را بهعنوان معيارى براى جايكزينى روايى و پايايى مطرح ساختهاند كه متشكل از جهار مفهوم جزئىتر

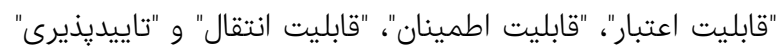

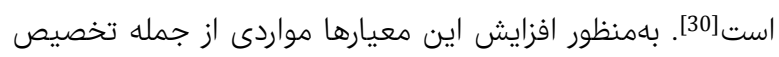

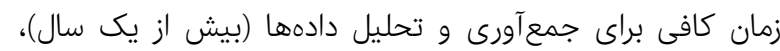

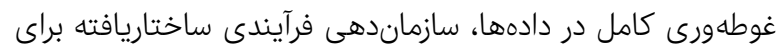

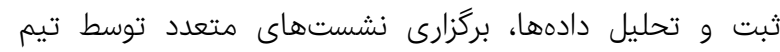

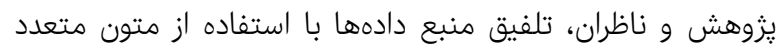

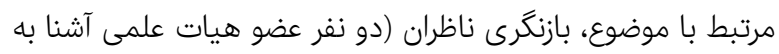

صحرايى[27] و توسعه ستادهاى امداد و انتقال در طول هشت سال دفاع مقدس [28] يرداختهاند. بهطور كلى مىتوان گَفت كاركنان مراقبت بهداشتى خصوصاً يزشكان

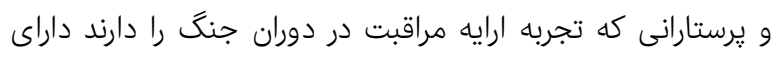

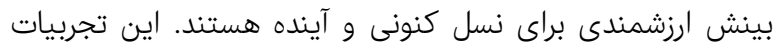

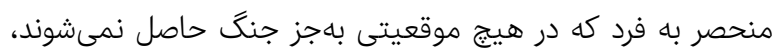

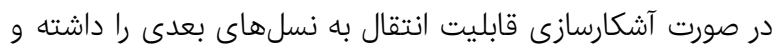

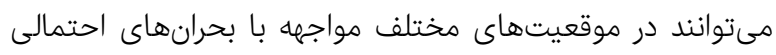

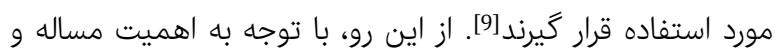

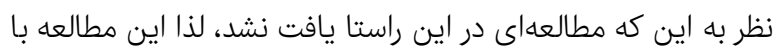

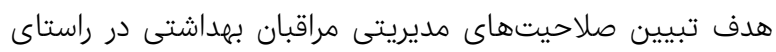

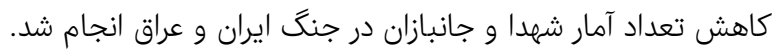

مشاركت كنندگان و روشها

اين يزوهش، يك مطالعه كيفى از نوع تحليل محتواى قراردادى يا مناديا

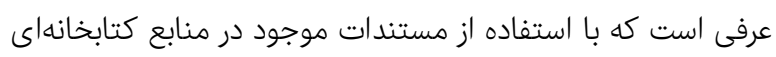

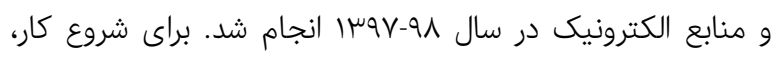

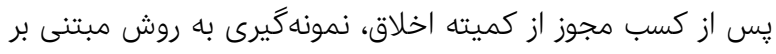

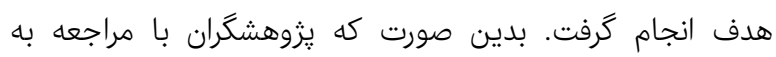

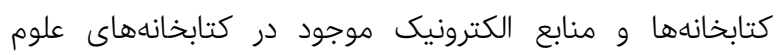

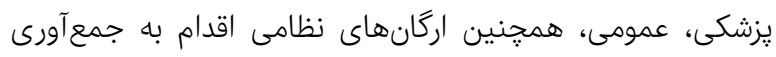

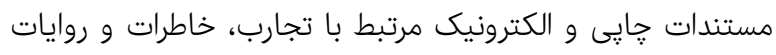

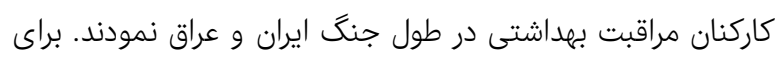

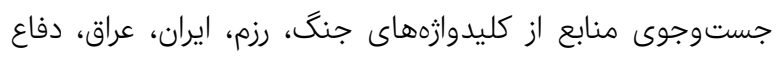

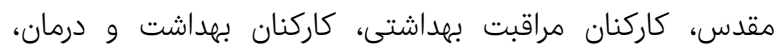

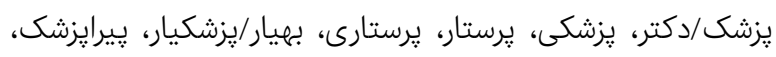

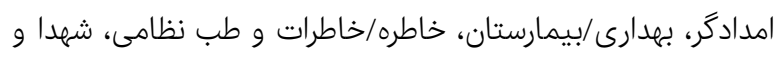

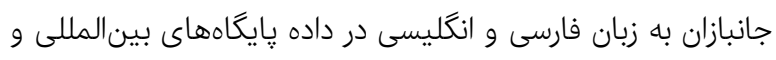

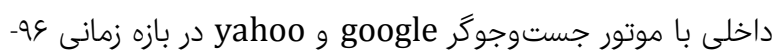

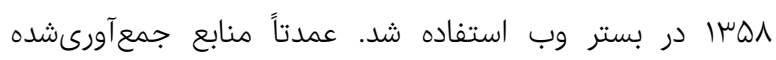
كتابهاى منتشرشده در اين حوزه بودند كه مورد تحليل قرار كَّار آرفتند.

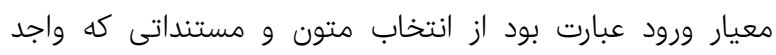

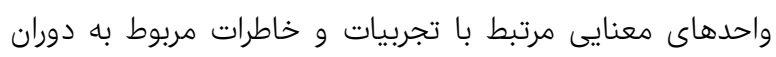

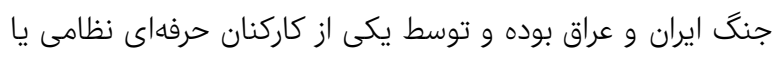

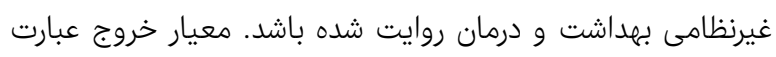

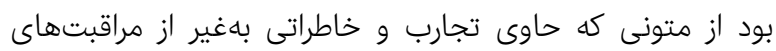

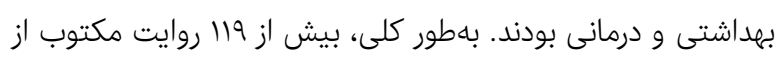

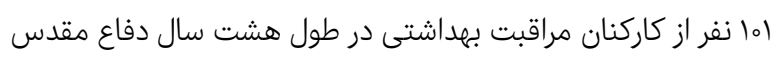

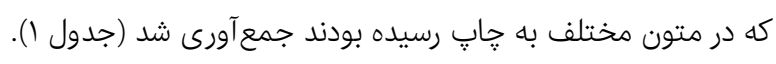

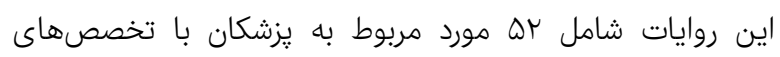

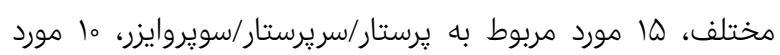

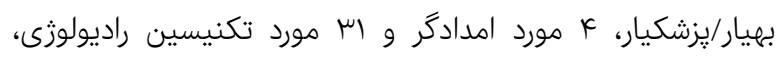

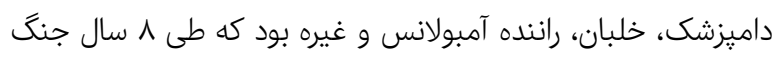
ايران و عراق بهعنوان تيم درمانى فعاليت داشتند. از آنجايى كه در آندان 
يافتهها

نتايج حاصل از تحليل بهو صفحه از خاطرات ثبتشده كاركنان

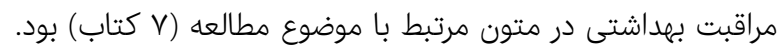

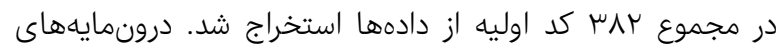

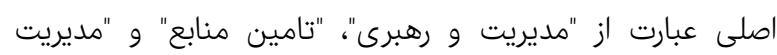

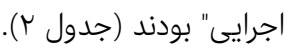

جدول (برونمايهها و زيردرونمايههاى مستخرج از دادهها

\begin{tabular}{|c|c|}
\hline تعداد كدها & درونمايهها و زيردرونمايهها \\
\hline & • مديريت و رهبرى \\
\hline$\Delta$ & ا- برنامهريزى \\
\hline I & r- سازماندهى و هماهنكَى \\
\hline v & س- مهارت تصميم گيرى و ريسكيذيرى \\
\hline \multirow[t]{3}{*}{ k } & F- ثبات مديريت \\
\hline & • تامين منابع \\
\hline & الف) تامين منابع انسانى \\
\hline$\Delta \Delta$ & 1- تامين كمى و كيفى نيروى انسانى \\
\hline 4 & r- مرزهاى نقش كاركنان \\
\hline द & س- يشتيبانى \\
\hline \multirow[t]{2}{*}{ k } & F- اختيارات و مسئوليتها \\
\hline & ب) تامين منابع فيزيكى \\
\hline lif & 1- فضاى فيزيكى \\
\hline $\mid m$ & r- امكانات و تجهيزات \\
\hline r & س- تبعيض و سوگيرى برخى مديران \\
\hline \multirow[t]{2}{*}{10} & ץ- تجهيزشدن \\
\hline & • مديريت اجرايى \\
\hline$\mu_{\circ}$ & 1- آمادگى (صفآرايى) \\
\hline sq & r- اقدامات امنيتى و حفاظتى \\
\hline$r \mu$ & س- بى احتياطى و سهل انكارى \\
\hline$\wedge$ & א- ثبت مستندات \\
\hline
\end{tabular}

\section{• مديريت و رهبرى - مدرى}

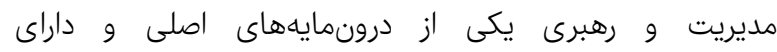

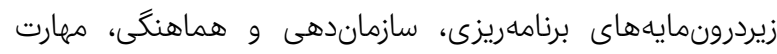
تصميمگيرى و ريسك يذيرى و ثبات مديريت بودئ

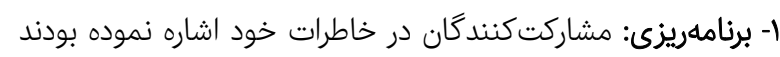

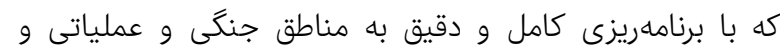

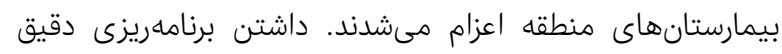
منجر به ييشبينىهاى صحيح و درمان سريعتر رزمندكان مى مئدان.

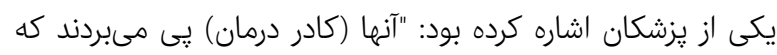

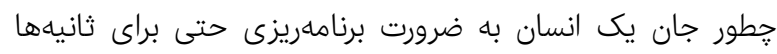

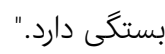

البته دادهها حاكى از آن بود كه در ابتداى جنگ بردنامه منسجمى

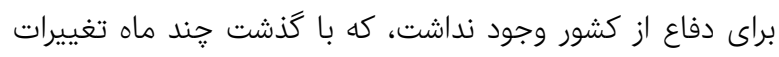

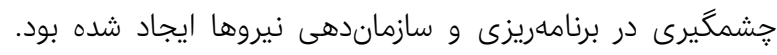

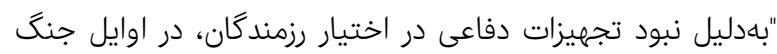

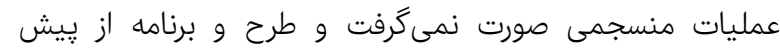
تعيينشداى وجود نداشت." منورت
روش مطالعه كيفى)، جستوجوى مدارى و شواهد رداهي ردننده و وارو

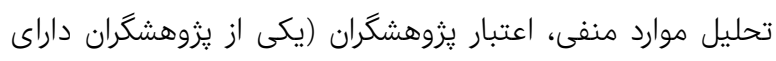

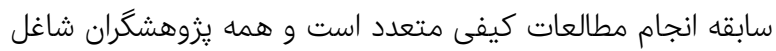
در محيط نظامى بوده و با رزمندگان دوران دفاع مقدس و و با كاركنان

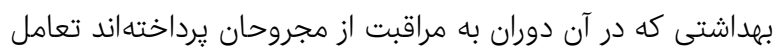

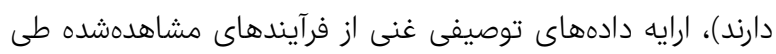

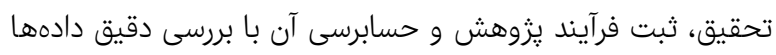

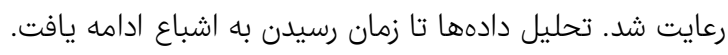

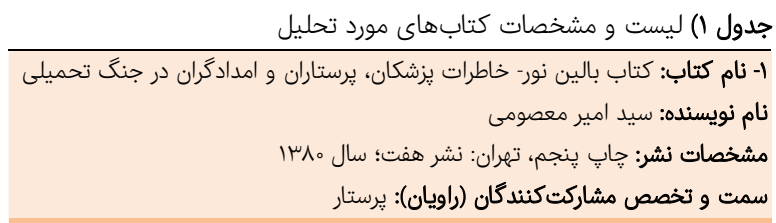

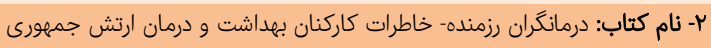

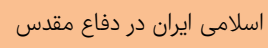

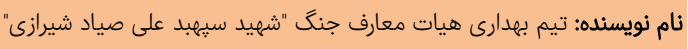

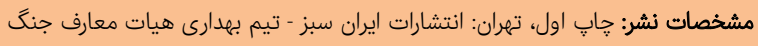

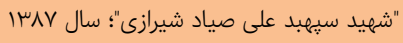

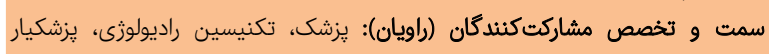

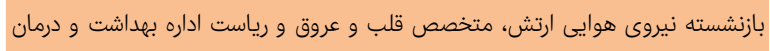

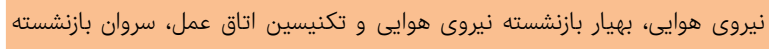

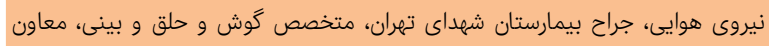

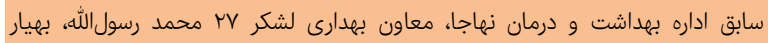

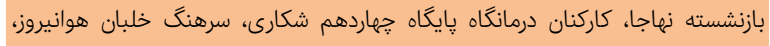

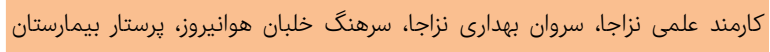

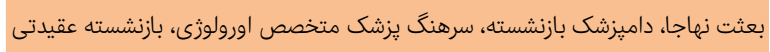

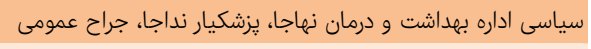

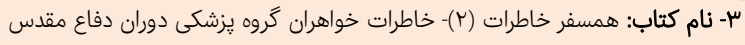

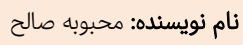
مشخصات نشر: جاب اول، موسسه آموزش عالى علمى كاربردى هلال احمر: سال عمسار

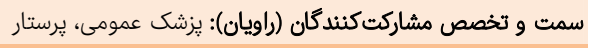

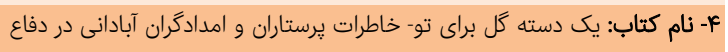
مقدس نام نويسنده: يروين كاشانىزاده

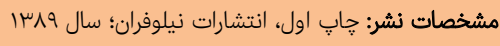

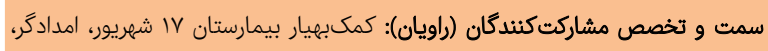

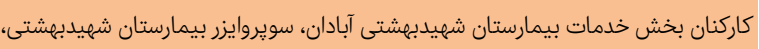

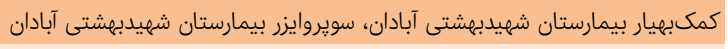

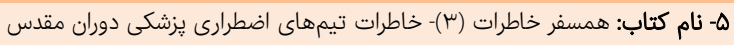

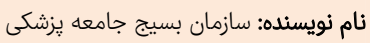

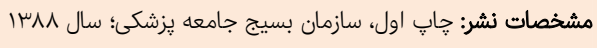

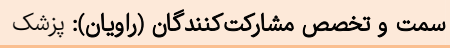

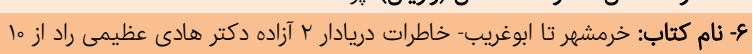
سال اسارت

نام نويسنده: تيم بهدارى هيات معارف جنگ "شهيد سيهبد على صياد شيرازى"

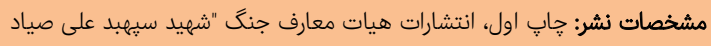

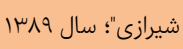
سمت و تخصص مشاركت كنندكان (راويان): دكتراى داميزشكى و متخصص علوم

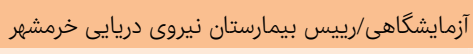

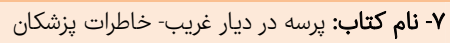

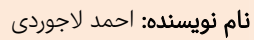

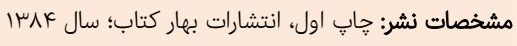

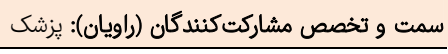




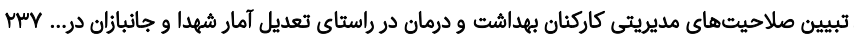

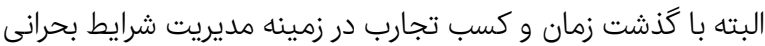

اين مشكل تا حدودى تعديل شده بود. در مواردى به قدرى بار كارى، بالا و نيروىهاى تخصصى اندى بـى بود بود

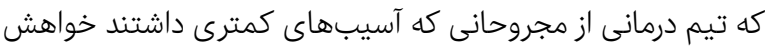

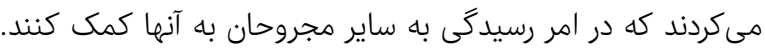

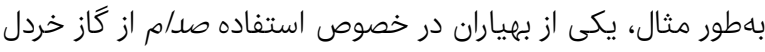

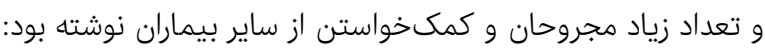
"... زدن آميول كزاز به همه آنها (مجروحان شيميايى) و برداشتن

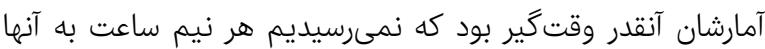

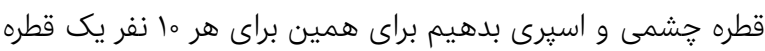

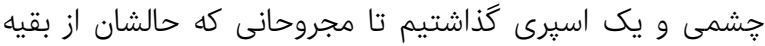

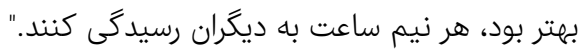
كمبود نيروى انسانى به مسالهاى حاد و بغرنج تبديل شده بون بودئ

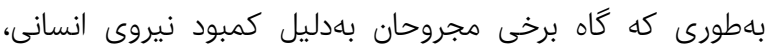

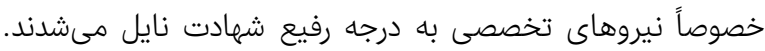

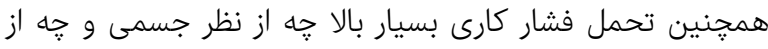

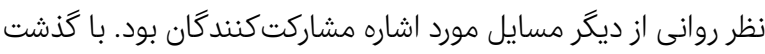

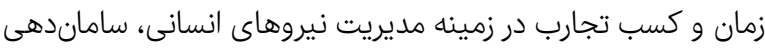

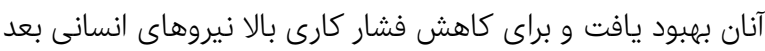
از مدتى با افراد تازمنفس جايكزين مى شيدند. خصوصاً در حملات

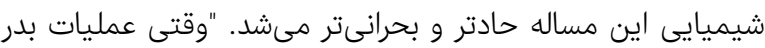

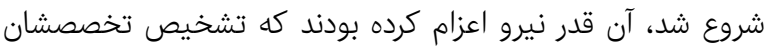

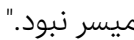
با توجه به كمبود شديد نيروهاى تخصصى، حضور بانوان در

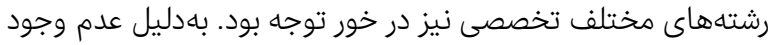
امنيت در مناطق نظامى تلاش مىشد كه خانمها از منطقه خارج

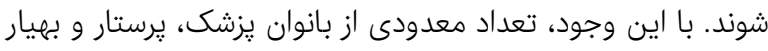

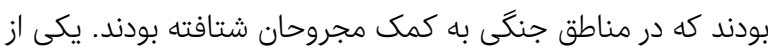

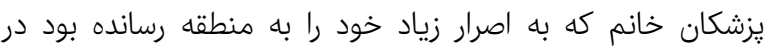

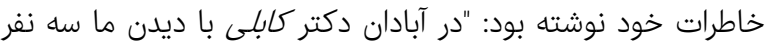

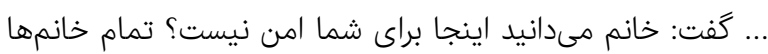

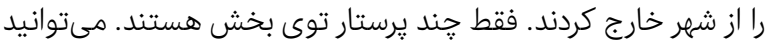

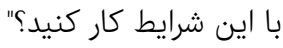
r- مرزهاى نقش كاركنان: كمبود نيروى انسانى به قدرى حاد بود

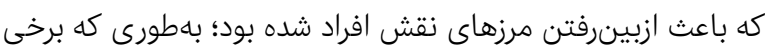

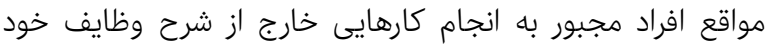

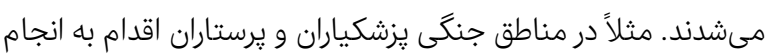

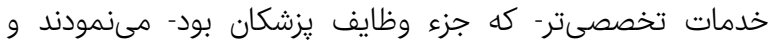

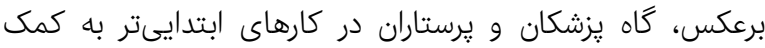

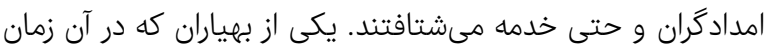

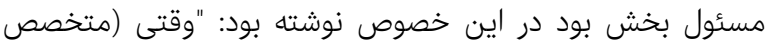

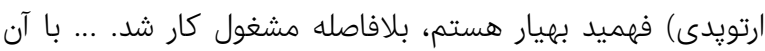

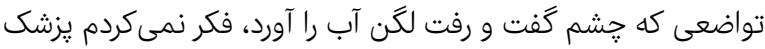
متخصص باشد. براى آتلبندى كمكش كردم." رون

r- سازماندهى و هماهنگى: نياز به سازماندهى دقيق و هماهنكى

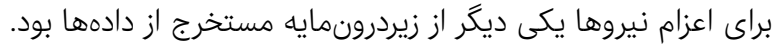

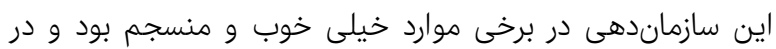

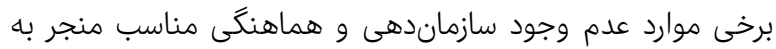

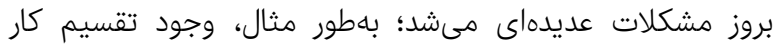

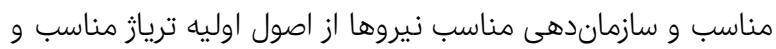

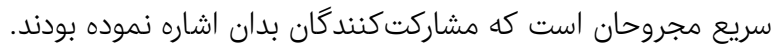

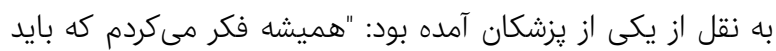

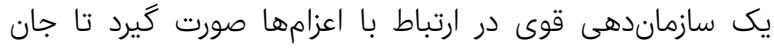

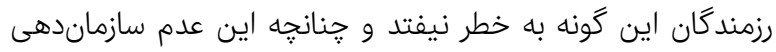

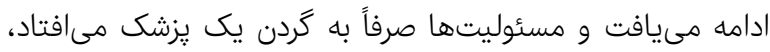
جقدر بىانصافى بود و جُقدر ناراحت كننده!"

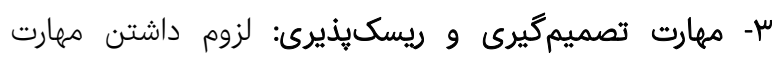

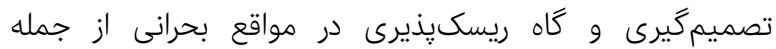

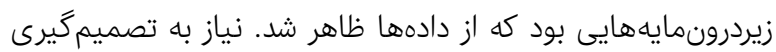

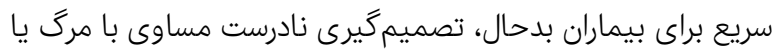

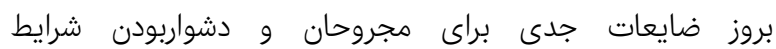
تصميم گيرى براى كاركنان از جمله مواردى بود كه مشاركت كنندگًان

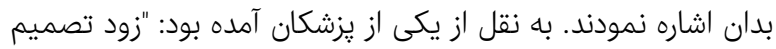

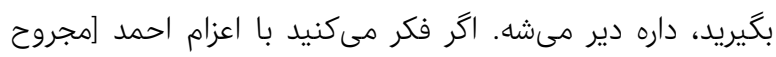

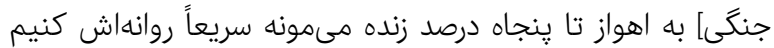

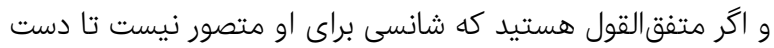

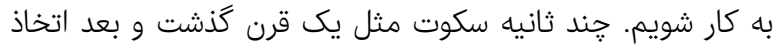

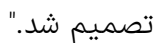
F- ثبات مديريت: يكى ديكر از زيردرونمايههاى مستخرج از دادهها

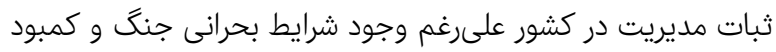

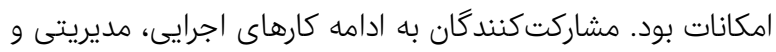
آموزشى علىرغم وجود جنگ در كشور اشاره كرده بودند. بهطور مثال،

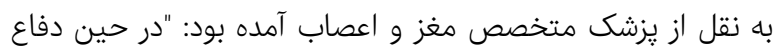

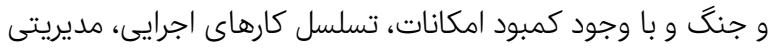
و آموزشى لحظهاى قطع نشد. حتى آموزش دستيارى و برگزارى

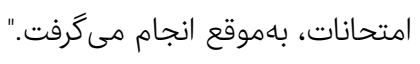

\section{• مامين منابع}

مديريت منابع از ديكر درونمايههاى ظاهرشده از دادهها بود كه به

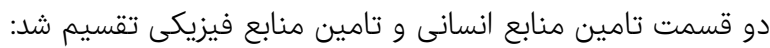
الف) تامين منابع انسانى اين مفهوم شامل تامين كمى و كيفى نيروى انسانى، مرزهاى نقش انسانى

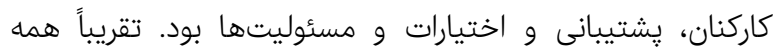
مشاركتكنندكان در يزوهش بـاني كمبود نيروى انسانى خصوصاً در اوايل جنگ اشاره نمودند: ا- تامين كمى و كيفى نيروى انسانى: يافتهها حكايت از آن داشت

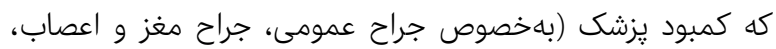
متخصص بيهوشى، ارتويد)، يرستار، يزشكيار و امدادگر كاملاً مشهود جهرد

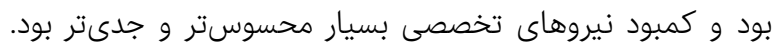


امكانات براى رسيدگى به مجروحان در زمان حمله به حلبجه گَفت:

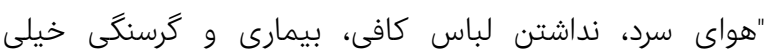

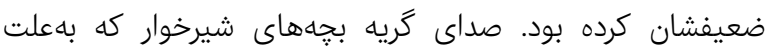

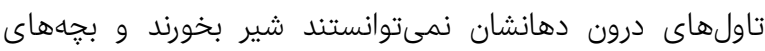
بزرگتر كه درد داشتند قطع نمى دراند."

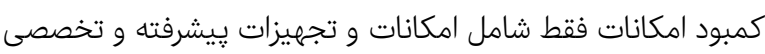

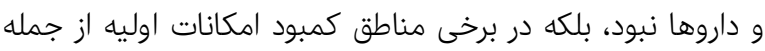

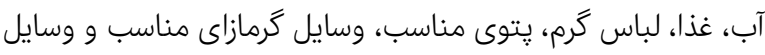

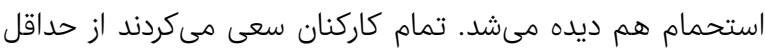

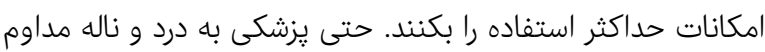

مجروحان از درد و كرسنگى اشاره نموده بود.

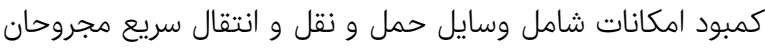

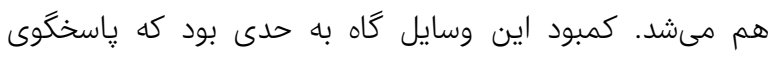

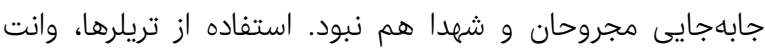

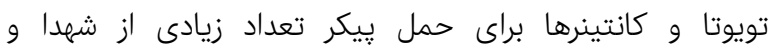
انباشتهشدن بيكر آنان بر روى يكديكر از جمائه

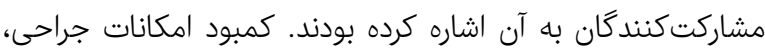

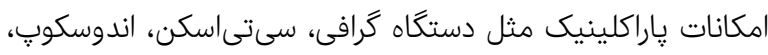

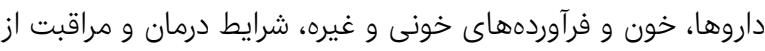

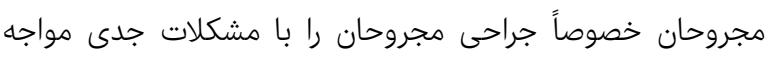

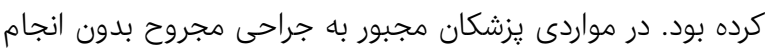

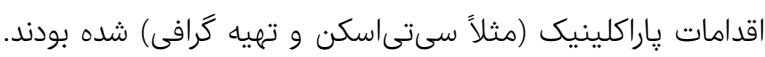

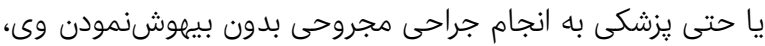

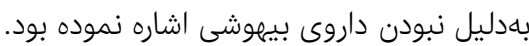

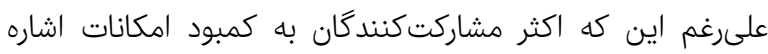

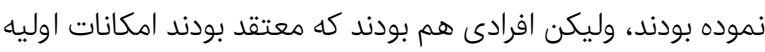

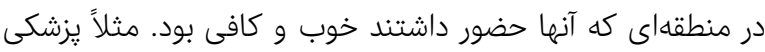

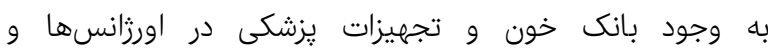

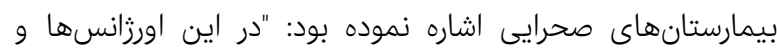

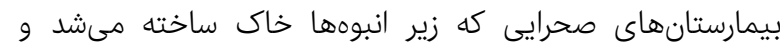

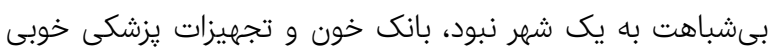

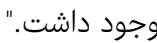
س- تبعيض و سوكيرى برخى مديران: گاه در ميان داده به جشم

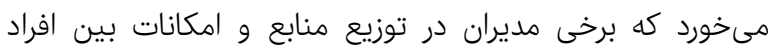

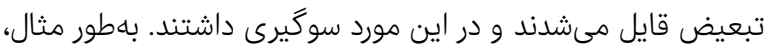

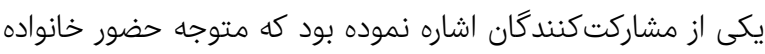

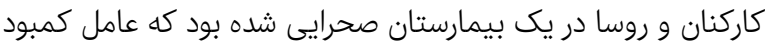

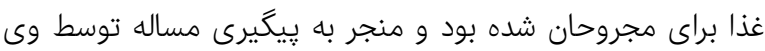

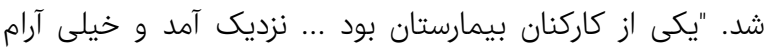

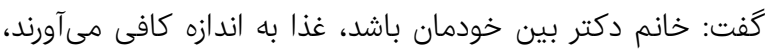

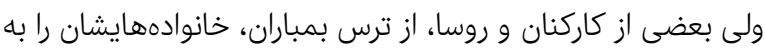

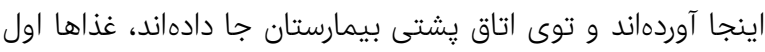

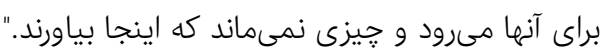

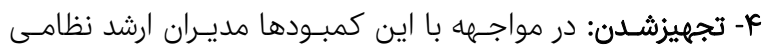

همجنين كمك به وضع حمل يك خانم باردار توسط يك دانشجوى

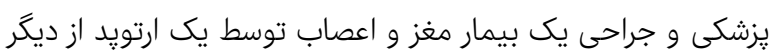

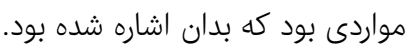

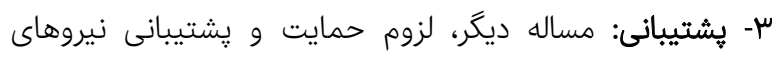

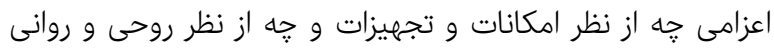

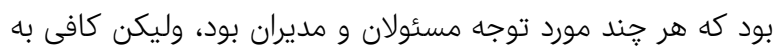

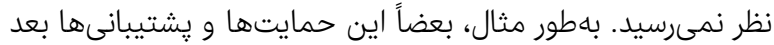

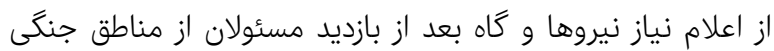

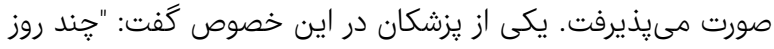

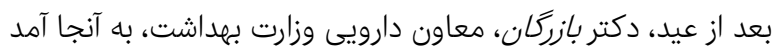

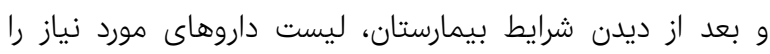

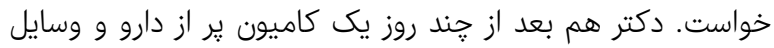

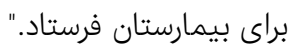

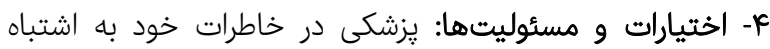

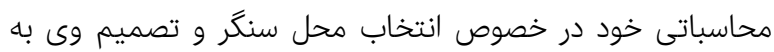

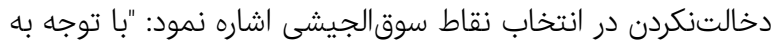

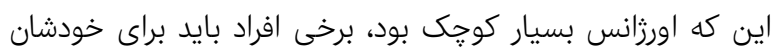

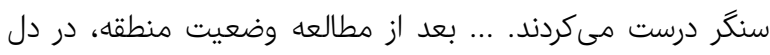

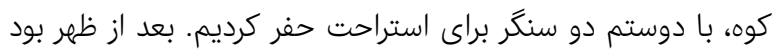

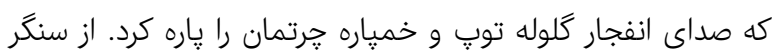

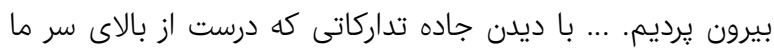

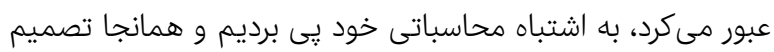

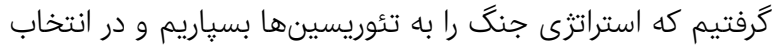
نقاط سوقالجيشى دخالتى نكنيم."

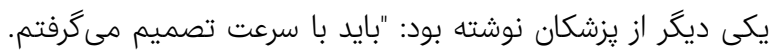

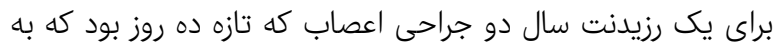

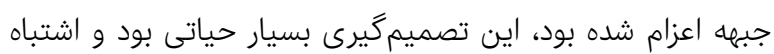

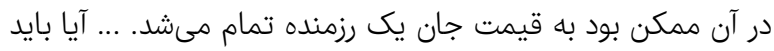

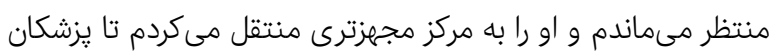

باتجربهترى او را عمل مى بكردند يا خود اقدام مىكردم. ...."

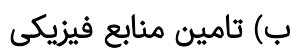
ا- فضاى فيزيكى: كاه با افزايش تعداد مجروحان، فياني فضاى فيزيكى

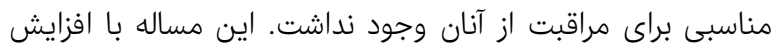

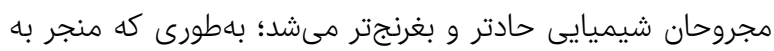

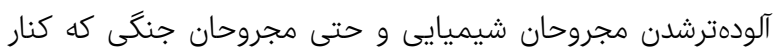

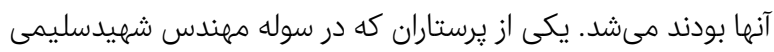

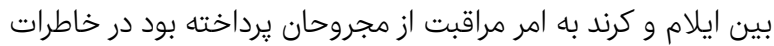

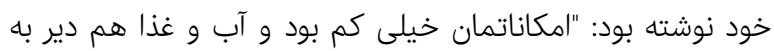

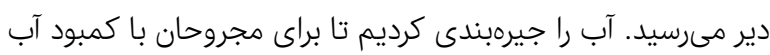

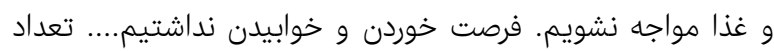

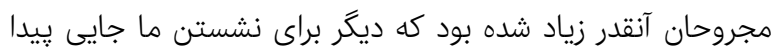
نمى شد." r- امكانات و تجهيزات: يكى از مشاركت كنندكان كه در آن زمان بهعنوان بجيار در منطقه مشغول به خدمت بود در خصوص كمبود آنان 


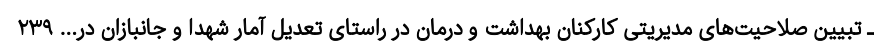

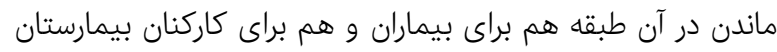

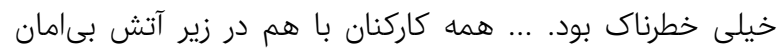
دشمن بخش اطفال را خالى كرديم." علاوه بر مسايل ايمنى و حفاظتى، رعايت موارد امنيتى كلى كليه

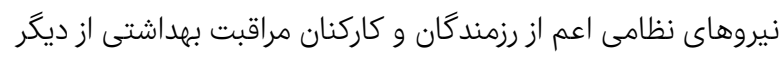

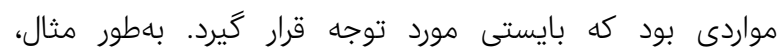

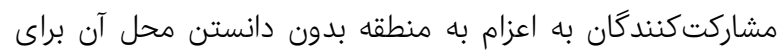

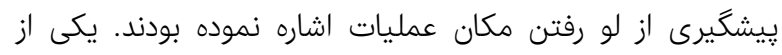

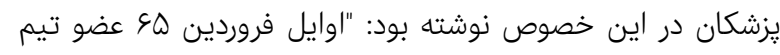

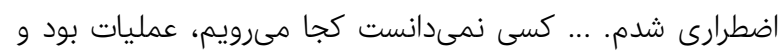

$$
\text { نبايد مكانى لو مىرفت." }
$$

اعزام اضطرارى نيروها به جبهه بدون اطلوناع مبه به خانواده، حفظ اسرار

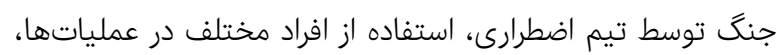
معدومكردن اسناد و مدارك نظامى توسط امدادگر حين اسارت،

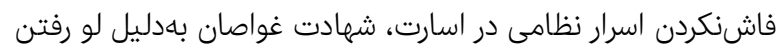

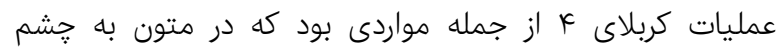

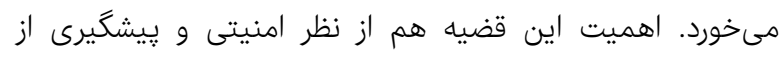

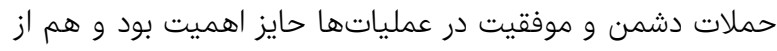
نظر حفظ روحيه كاركنان. بهطورى كه تعدادى از كاركنان تيم درمانى مونى و مجروحان مدتى در ايلام در محاصره دشمن بودند، در حالى كه به له

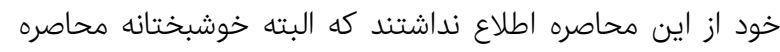

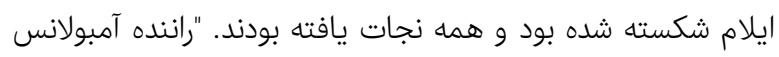

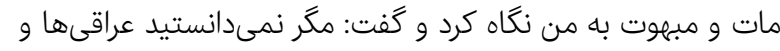

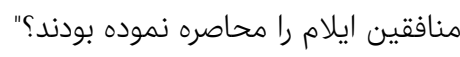

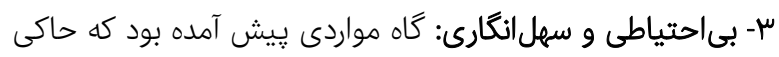

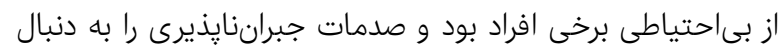

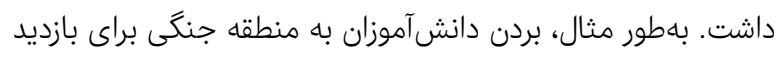

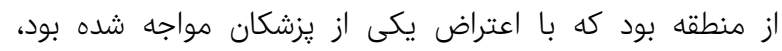

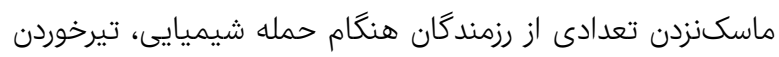

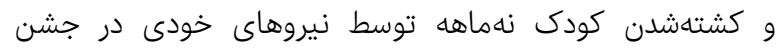

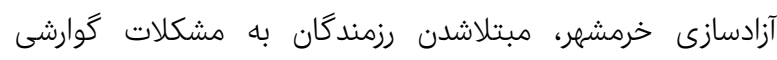

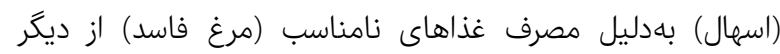

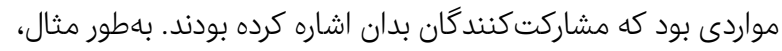

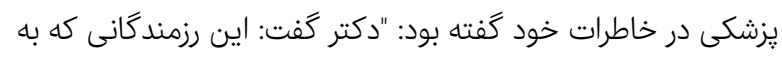

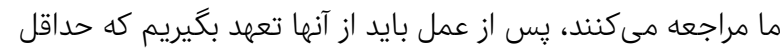

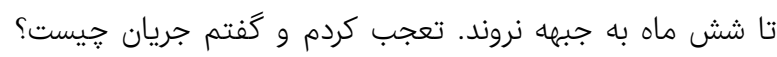

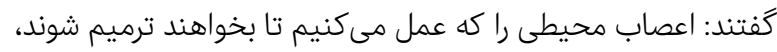

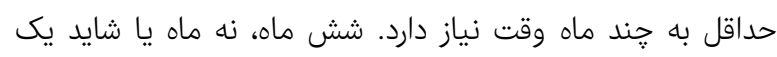

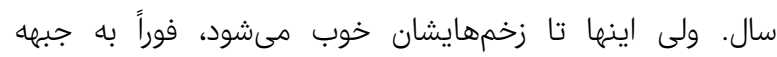

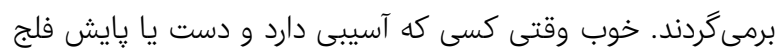

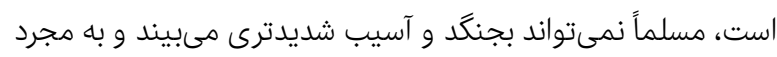

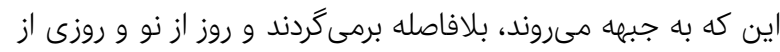

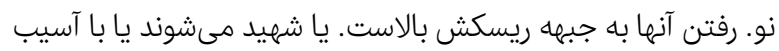

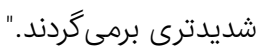

بىتفاوت نبودند و تمام تلاش خود را مىنمودند تا امكانات و

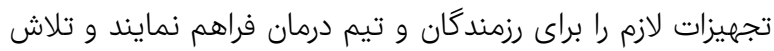

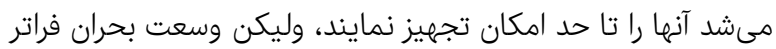

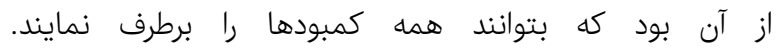
مشاركت كنندگًان نيز به مجززبودن برخى بيمارستانها، اتاق عملها،

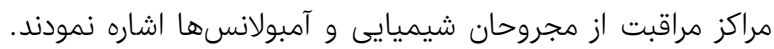

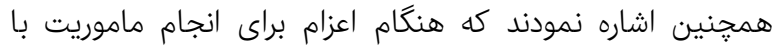
تجهيزات كامل به منطقه مورد نظر اعزام مىشدند. بهطور مثال، به نهونه نقل از يزشكى آمده بود: "اولين بار بود كه در يك جاى نسبتاً مجهز مُهز

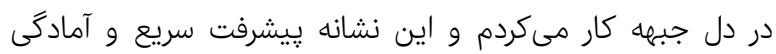

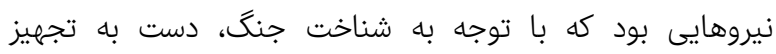

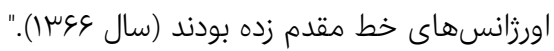

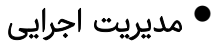

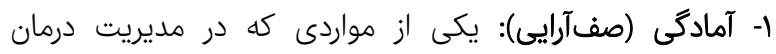

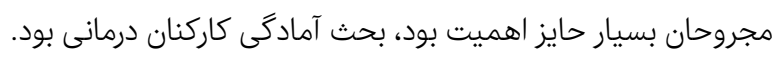

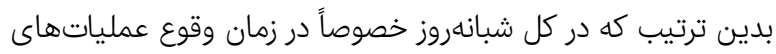

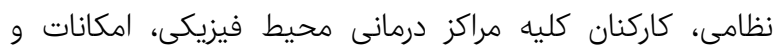

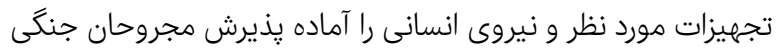

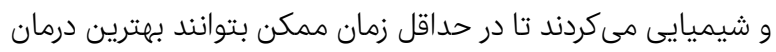

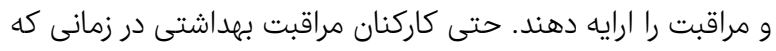

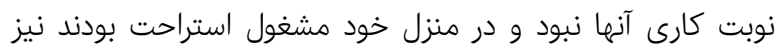

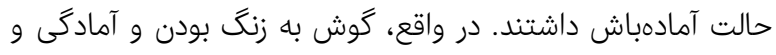

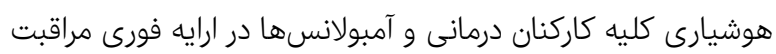

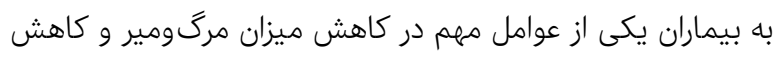

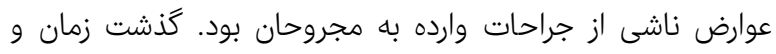

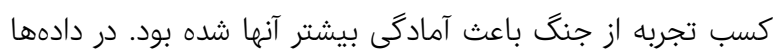

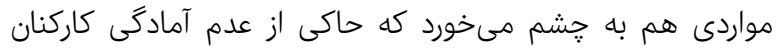

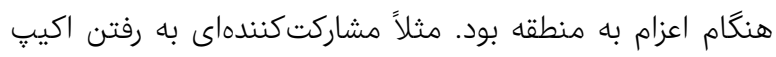

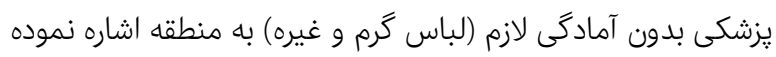

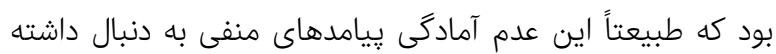

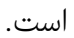

r- اقدامات حفاظتى و امنيتى: از آنجايى كه دشمن حتى به

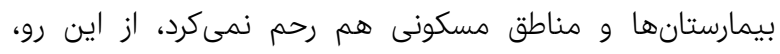

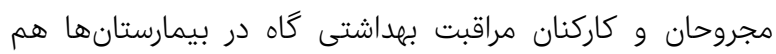

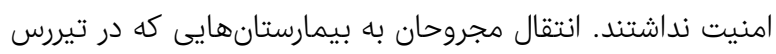

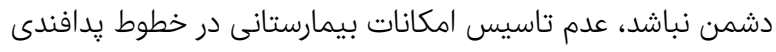

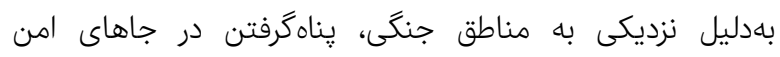

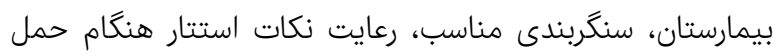

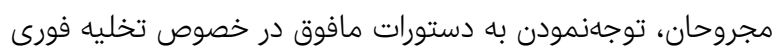

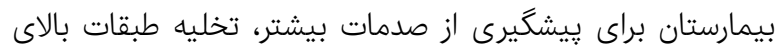

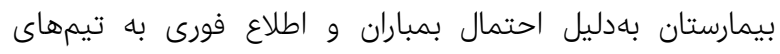

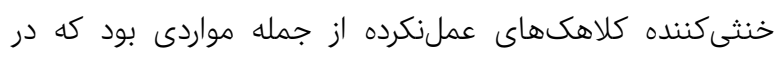

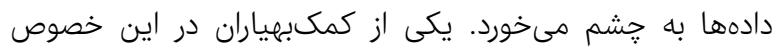
نوشته بود: "بيمارستان در تيررس مستقيم دشمن بود و در آن شرايط 


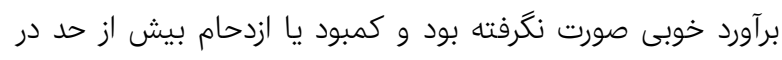

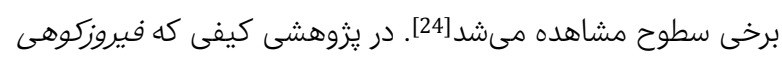

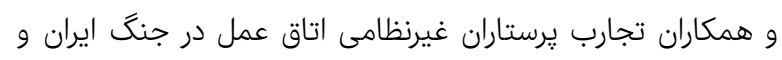

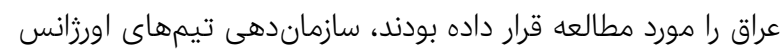

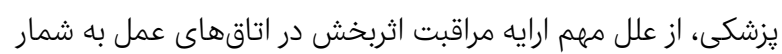

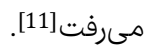

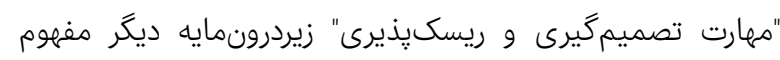

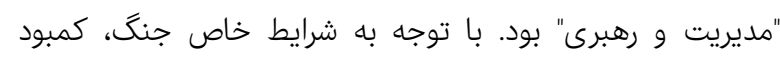

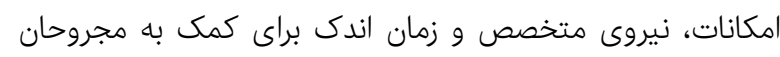

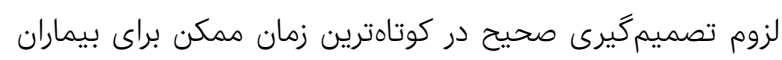

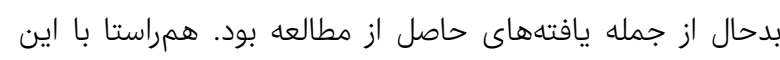

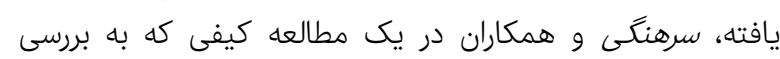

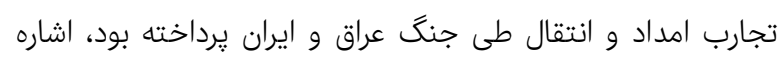

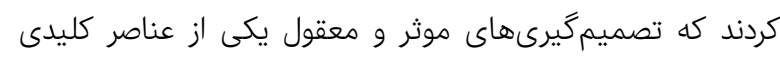

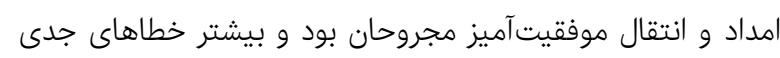

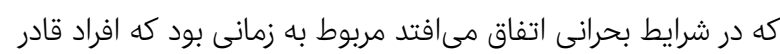

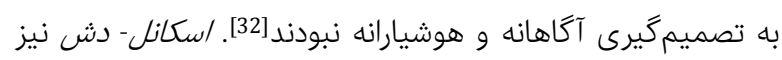

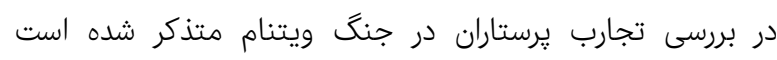

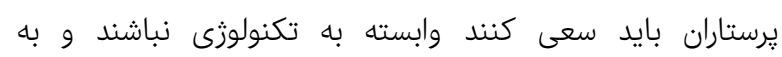

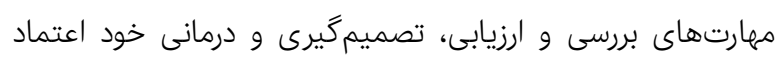

كنيد [19].

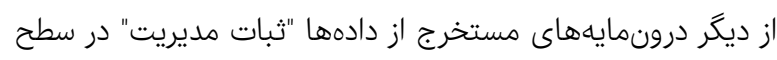

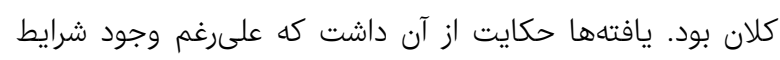

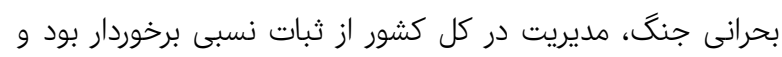

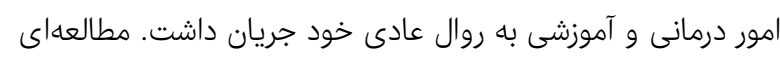

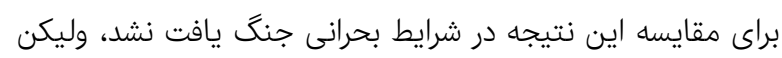

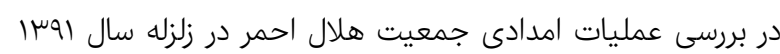

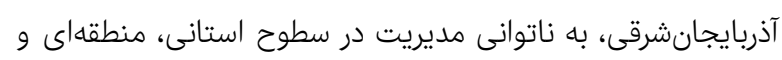

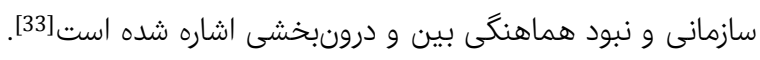

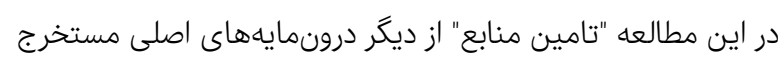

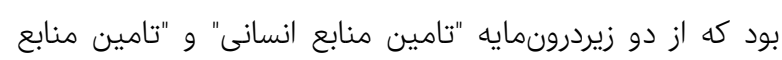

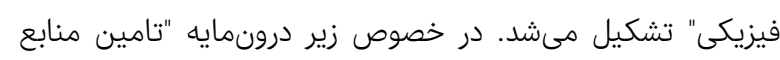

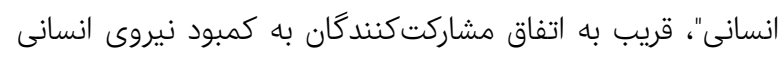

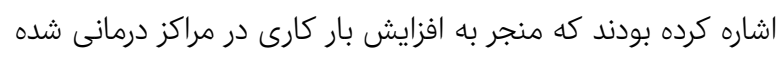

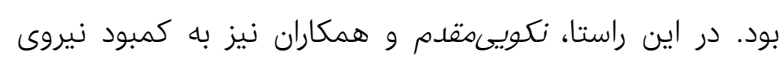

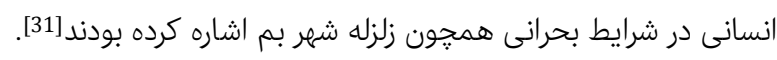

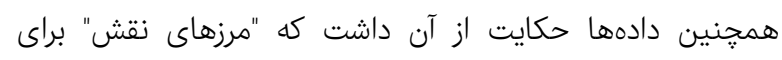

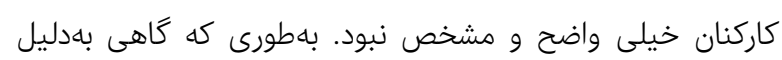

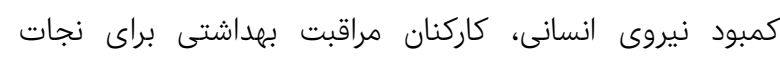

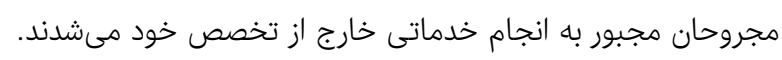

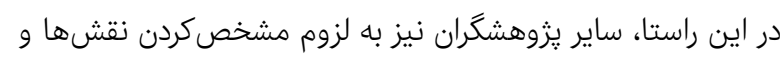

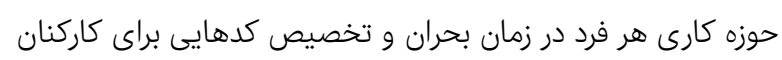

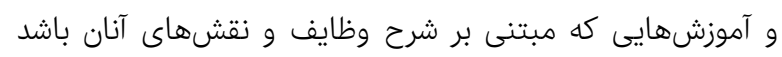

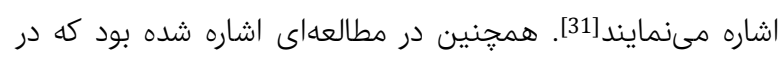

F- ثبت مستندات: مشاركت كنندكان بهان لزوم ثبت مشخصات

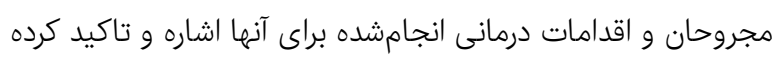

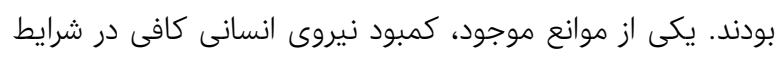

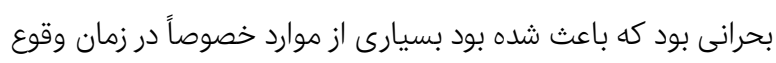

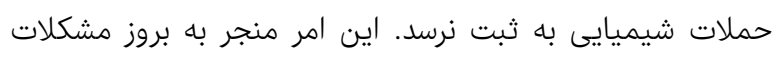

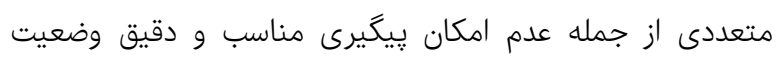

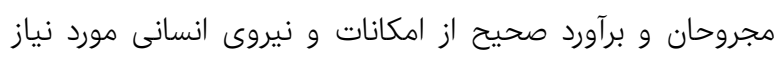

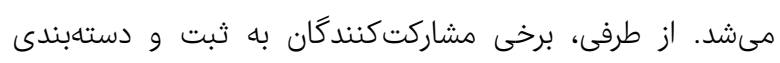

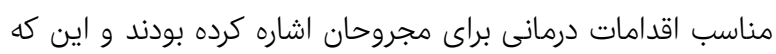

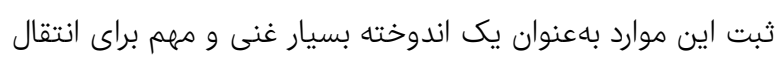

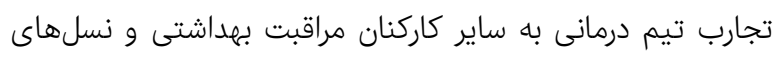

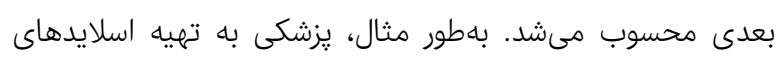

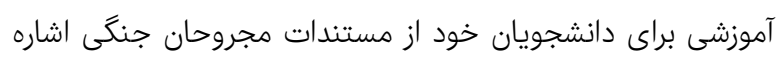

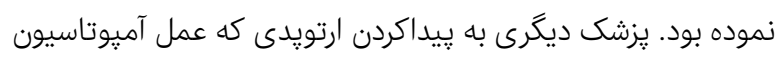

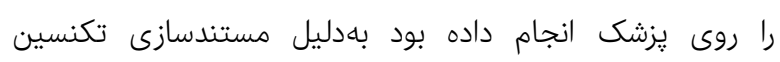

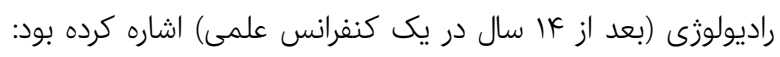

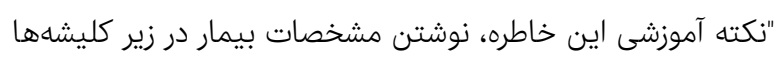

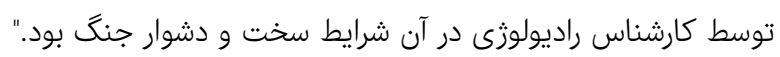

بحث اين مطالعه با هدف تبيين صلاحيتهاى مديريتى كاركنان بهداشت

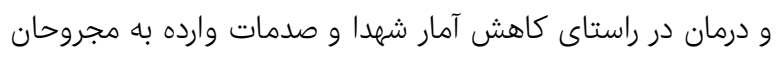

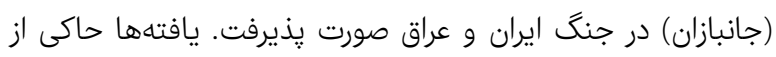

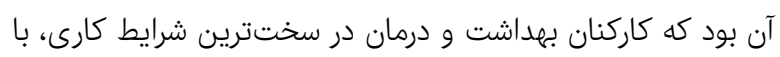

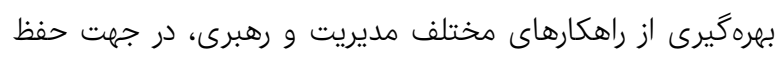

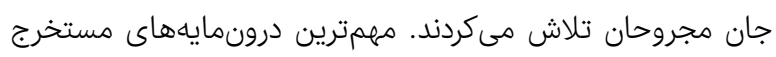

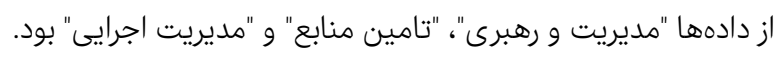

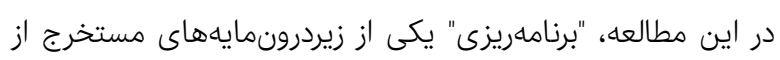

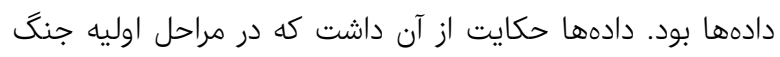

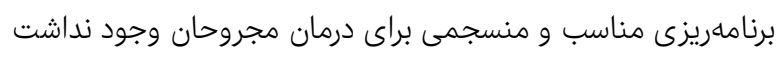

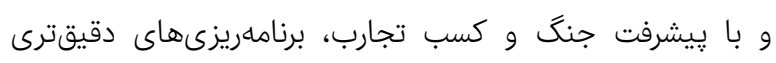

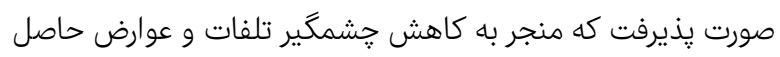

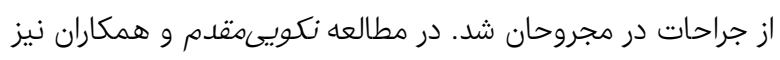

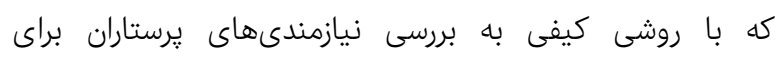

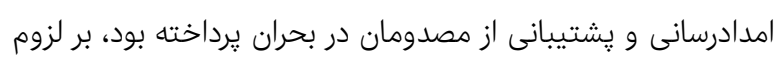

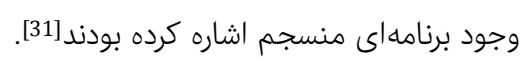

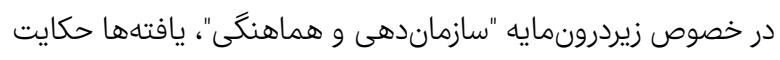

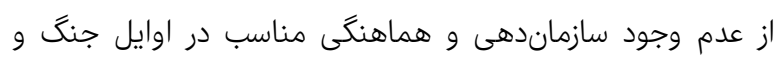

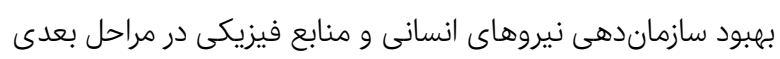

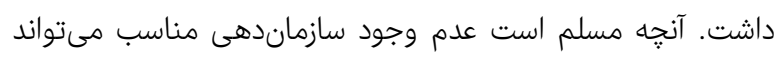

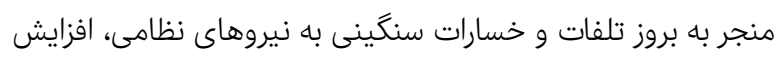

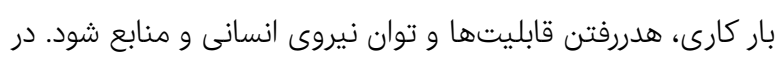

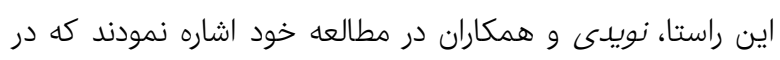

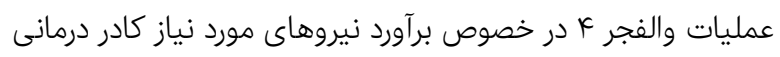


تبيين صلاحيتهاى مديريتى كاركنان بهداشت و درمان در راستاى تعديل آمار شهدا و جانبازان در... IFI

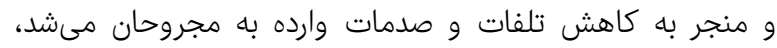
طول جنگ در نتيجه كمبود يزشك، مسئوليتهاى بين يزشكان و

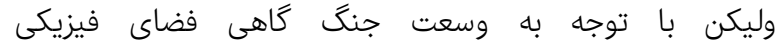
درنظرگرفتهشده براى حجم وسيع مجروحان جنان جنان مناسب

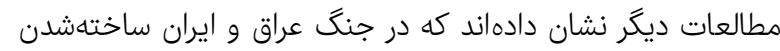

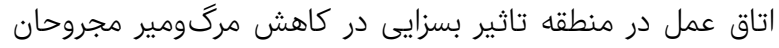

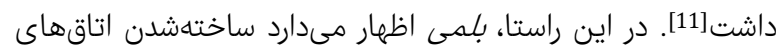

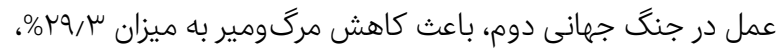

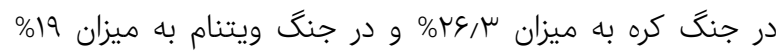
شد

همجنين كمبود امكانات و تجهيزات تخصصى و داروهاى مورد نياز

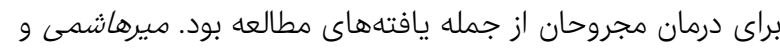

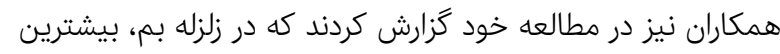

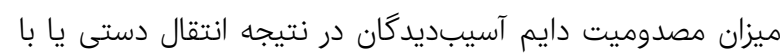

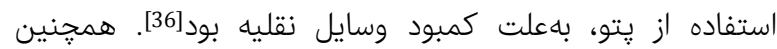

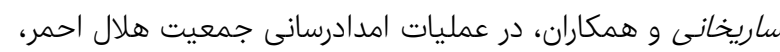

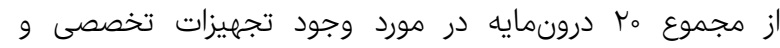

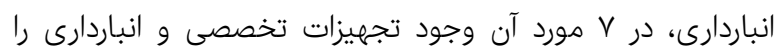

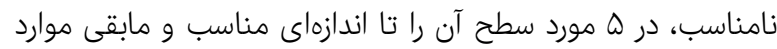

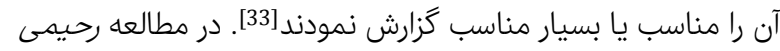

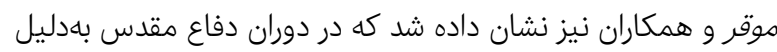

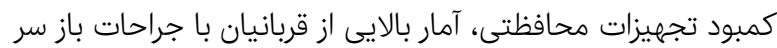

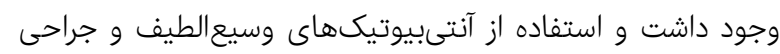
در بيمارستانهاى بزرگ مهمترين عامل در حفظ حيات و كاهش عوارض اين قربانيان بود[26]. يافتههاى اين مطالعه حاكى از مناسببودن تعيين إنوان محل احداث

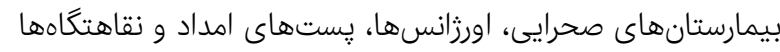
است كه با يافتههاى مطالعه نويدى و همكاران [24] همخوانى دارئي دارد.

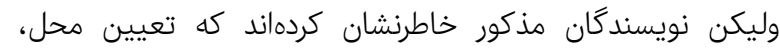

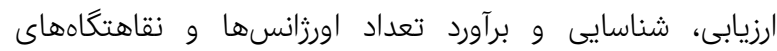
مصدومان شيميايى با نيازهاى عمليات مغايرت داشت كه اين يافته

نيز با مطالعه حاضر همخوانى دارد.

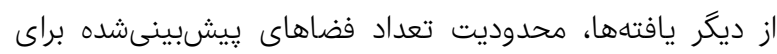

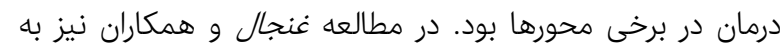

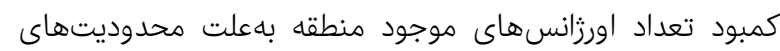

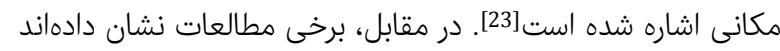

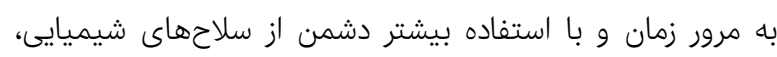

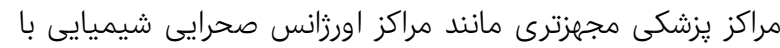
تسهيلات تخصصىتر و وضعيت بهتر تامين دارو شكل گرفتند [13]. غنجال و همكاران در مطالعه ديكر خود عنوان كردند كه در ابتداى

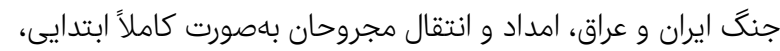
خودجوش و بدون هماهنكى انجام مى

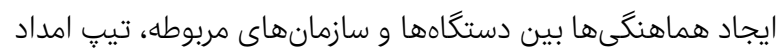

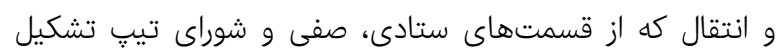
مىشد، شكل گرفت كه داراى قدرت عملياتى بالايى بود [27].

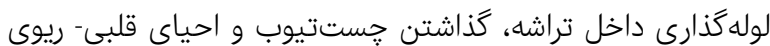

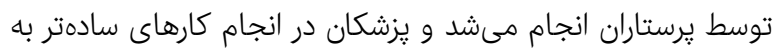

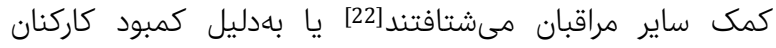
متخصص يزشكى (مثل جراح يا بيهوشى)، يرستاران بهاعنوان كمكبيهوشى يا ديكر تخصصهاى يزشكى فعاليت مى مردند [22]. در

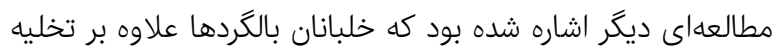

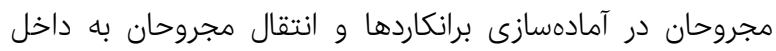
بالكرد نيز كمك مى كردند. بديهى است كه حس حس همكارى مضاف بران

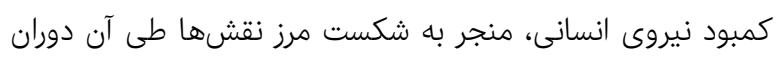

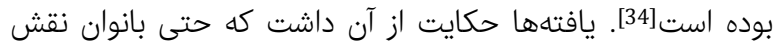

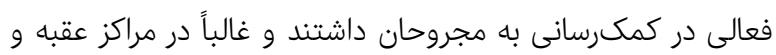

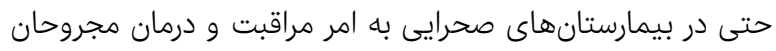

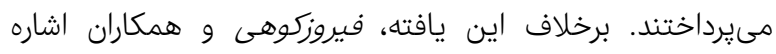
مىكنند كه در بيمارستانهاى صحرايى و مراكز اورزانس، هيج يرستار خانمى مشغول فعاليت نبود[22].

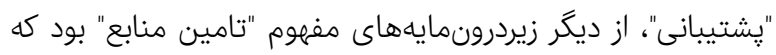

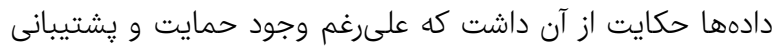

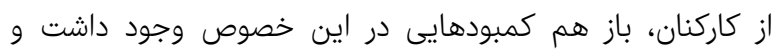

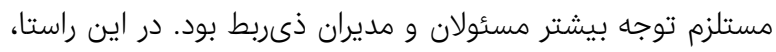

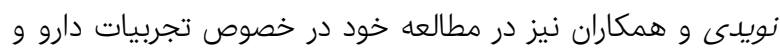

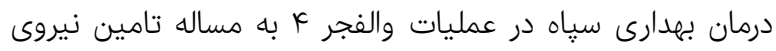

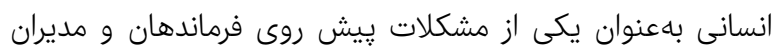

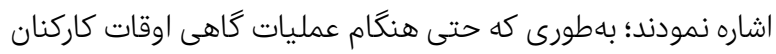

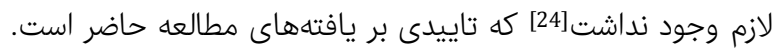

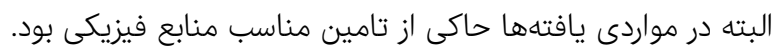

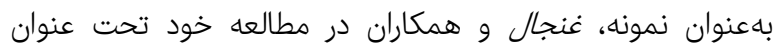

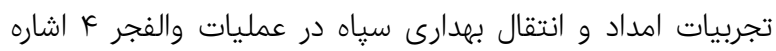

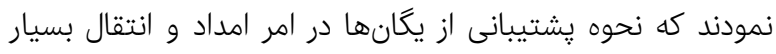

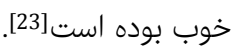

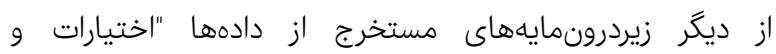
مسئوليتها" بود. مشاركتكنندگًان به استفاده از افراد در جايكاه تخصصى خود و لزوم عدم دخالت افراد در امورى كه تخصص لازم

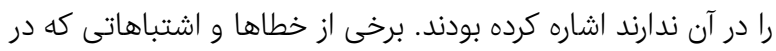

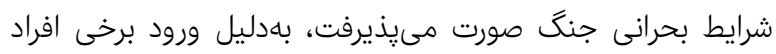

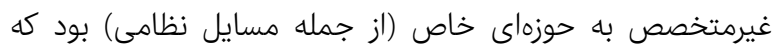

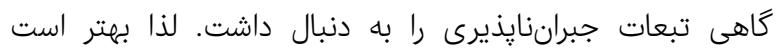
رسيدگى به مسايل نظامى به كاركنان تخصصى مربوطه (نظاميان)

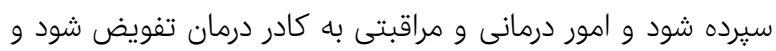
افراد از دخالت در امورى كه تخصص ود تبحر لازم را ندارند بيرهيزند.

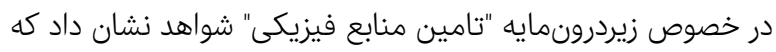

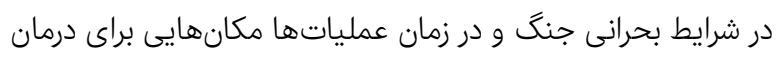

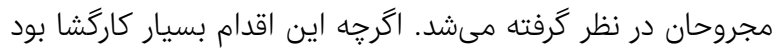


راستا، در مطالعهاى ثبت مداخلات يزشكى از جمله يافتههاى كليدى

مستخرج از دادهها بود[11].

از جمله محدوديتهاى اين يزوهش عدم استفاده از روش مصادها بودبه

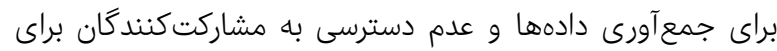

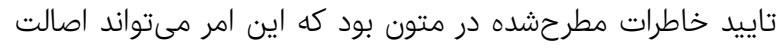

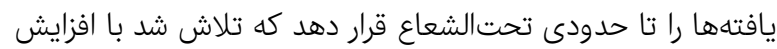

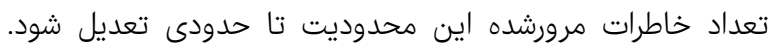
انجام مطالعات مشابه براى تبيين تجارب كاركنان بهداشت و دروات مدردان

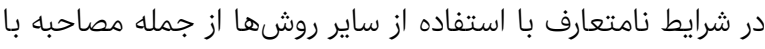

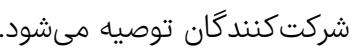

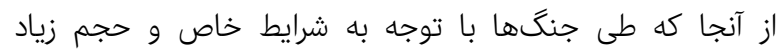
مجروحان، مشكلات متعددى از جمله سردرگمى، كمبود تجهيزات و و

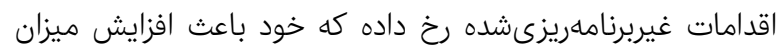
مركومير مصدومان مىشود، تبيين و درك درسآموختهها و تجارب دارهاب

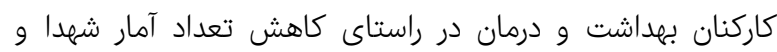
جانبازان طى ^ سال جنگ ايران و عراق مىتواند باعث افزايش دانش رانش

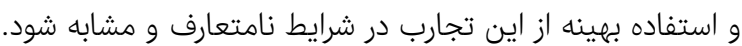

\section{نتيجه گيرى}

ملاحيتهاى مديريتى مراقبان بهداشتى شامل مديريت و رهبرى،

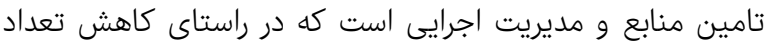
آمار شهدا و جانبازان در جنگ ايران و عراق به كار رفته است.

تشكر و قدردانى: اين مطالعه حاصل از يك طرح مصوب در دانشگاه

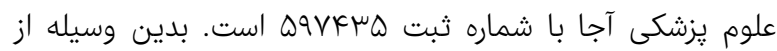

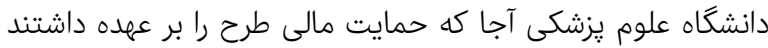

تشكر و قدردانى مىشود.

تاييديه اخلاق: يزوهش حاضر در كميته اخلاق دانشگاه علوم يزشكى

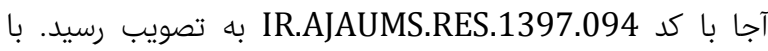
توجه به اين كه در اين مطالعه از اسناد و مدارك موجود استفاده

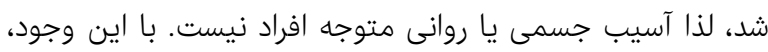

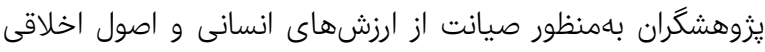
يزروهش، خود را ملزم به رعايت حقوق مولفان در استفاده از متون و و

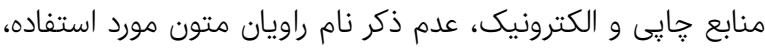

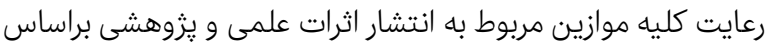

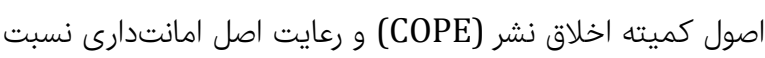
به متون و ذكر نقل قولها نمودند.

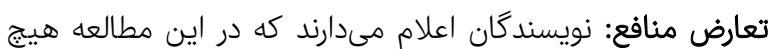
كونه تضاد منافعى وجود نداشت.

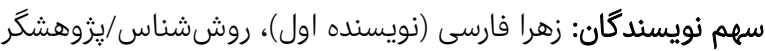

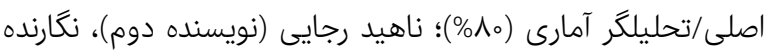

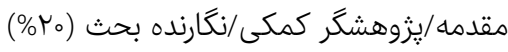

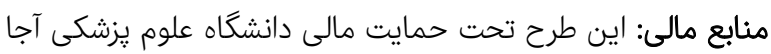

در مطالعه حاضر درونمايه "مديريت إنى اجرايى" با زيردرونمايههاى "آمادگى"، "اقدامات حفاظتى و امنيتى"، "بىاحتياطى و سهل دانگارى"

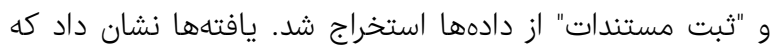

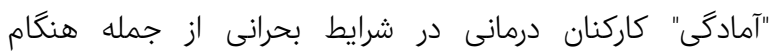

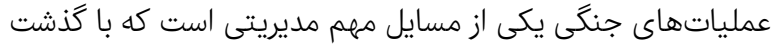

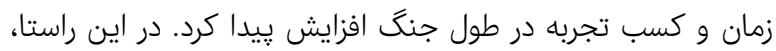

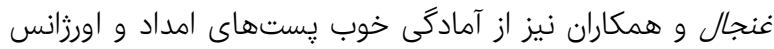
براى يذيرش مجروحان در عمليات والفجر \& ع ياد كردهاند[23]. فيروزكوهى و همكاران نيز در مطالعه خود بيان داشتند يرستارئن دران دران

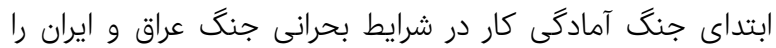

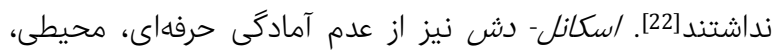

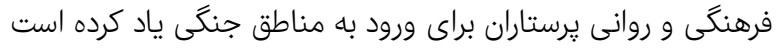

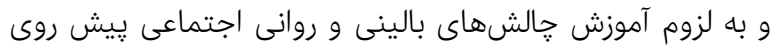

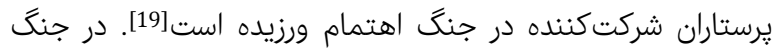

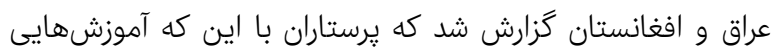

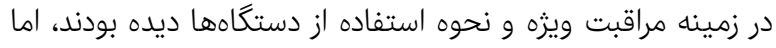

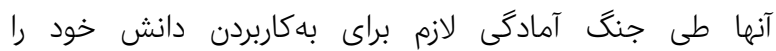

نداشتند[37].

در ارتباط با زيردرونمايه "اقدامات حفاظتى و امنيتى"، يافتهها

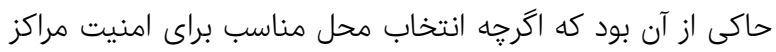

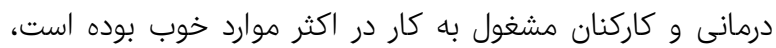

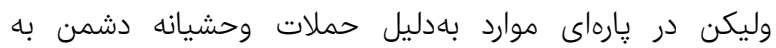

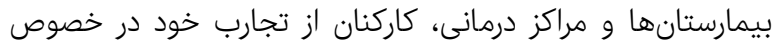

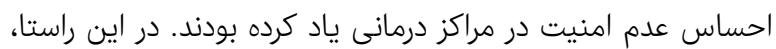

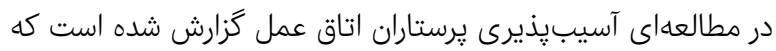

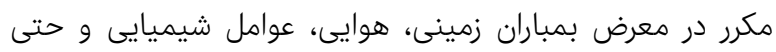

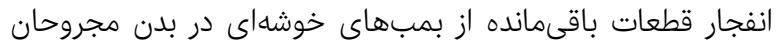

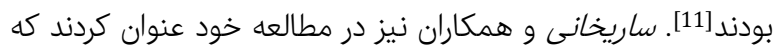
از نظر مديران هلال احمر، تامين امنيت اجتماعى در منطقه زلزلهزده

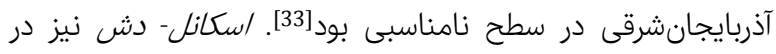

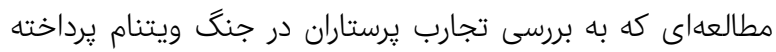

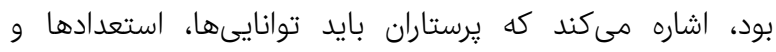
محدوديتهاى خود را براى مراقبت و محافظت از خود بشناسند [19].

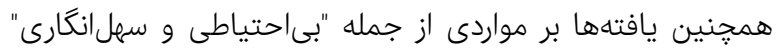

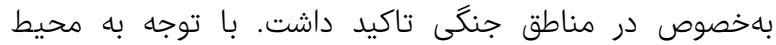

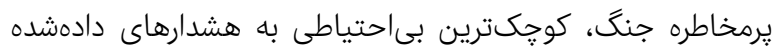

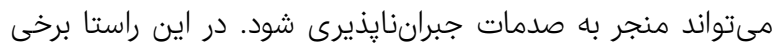

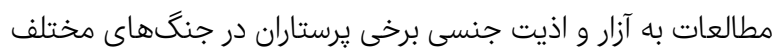
اشاره نمودند [30-40] لزوم "ثبت مستندات" از ديكر درونمايههاى مستخرج از دادهودها بود كه بهدليل كمبود نيروى انسانى آن طور كه بايد و شايد انجام

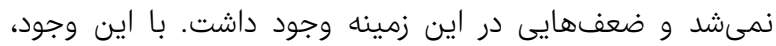

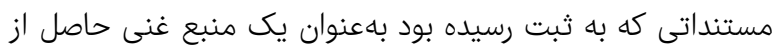

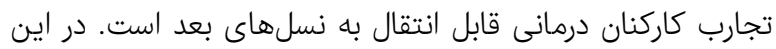




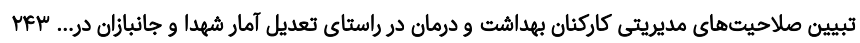

17- Elliott B. Military nurses' experiences returning from war. J Adv Nurs. 2015;71(5):1066-75.

18- Shamia NA, Thabet AA, Vostanis P. Exposure to war traumatic experiences, post-traumatic stress disorder and post-traumatic growth among nurses in Gaza. J Psychiatr Ment Health Nurs. 2015;22(10):749-55.

19- Scannell-Desch EA. Lessons learned and advice from Vietnam War Nurses: a qualitative study. J Adv Nurs. 2005;49(6):600-7.

20- Hallett CE. Containing trauma: nursing work in The First World War. Manchester: Manchester University Press; 2010.

21- Peyrovi H, Parsa-Yekta Z, Vosoughi MB, Fathiyan N, Ghadirian F. From margins to center: an oral history of the wartime experience of Iranian nurses in Iran-Iraq war, 1980-1988. Contemp Nurse. 2015;50(1):14-25.

22- Firouzkouhi M, Zargham-Boroujeni A, Nouraei M, Yousefi $\mathrm{H}$, Holmes CA. The wartime experience of civilian nurses in Iran-Iraq war, 1980-1988: an historical research. Contemp Nurse. 2013;44(2):225-31.

23- Ghanjal A, Sadri Arhami A, Basam SM. Rescue and transportation experiences of medical department of Sepah in Valfajr 4 operation. J Mil Med. 2003;5(2):91-8. [Persian]

24- Navidi AA, Ghanjal A, Sadri A, Abolghasemi H. Pharmaceutical and medical experiences Sepah in Valfajr 4 operation. J Mil Med. 2002;4(3):151-6. [Persian] 25- Haj Ahadi ST, Navidi AA, Abolghasemi H, Mohebbi HA. A review of medical experiences of Sepah in Holy Defense: Valfajr 4 Operation. J Mil Med. 2002;4(2):75-80. [Persian] 26- Rahimi-Movaghar V, Jazayeri SB, Alimi M, Abbassioun $\mathrm{K}$, Amirjamshidi A. Lessons learned from war: a comprehensive review of the published experiences of the Iranian neurosurgeons during the Iraq-Iran conflict and review of the related literature. World Neurosurg. 2013;79(2):346-58.

27- Ghanjal A, Ameryun A, Behrozinejad N, Motaghi M. Field hospitals in Iraq-Iran war. J Mil Med. 2004;6(2):14352. [Persian]

28- Ghanjal A, Motaghi M, Mirhashemi S, Delavari AR. Rescue and transportation brigade in Iraqi imposed war against IRAN. J Mil Med. 2005;6(4):285-92. [Persian]

29- Adib Hajbagheri M, Parvizi S, Salsali M. Qualitative research methods. 1 ${ }^{\text {st }}$ Edition. Tehran: Boshra Publication; 2007. p. 252. [Persian]

30- Rezapour Nasrabad R. Criteria of validity and reliability in qualitative research. J Qual Res Health Sci. 2018;6(4):493-9. [Persian]

31- Nekooei Moghaddam M, Saeed S, Khanjani N, Arab M. Nurses' requirements for relief and casualty support in disasters: a qualitative study. Nurs and Midwifery Stud. 2014;3(1):e9939.

32- Sarhangi F, Gholami HR, Khaghanizade M, Najafi Mehri S. First aid and transportation course contents based on experience gained in the Iran-Iraq War: a qualitative study. Trauma Mon. 2015;20(1):e23846.

33- Sarikhani N, Farsad H, ZareTousi Z, Najafi M, Mousavi AS, Oveisi N, et al. Studying the managers' viewpoint of East Azerbaijan provinces in 2012 and branches about relief operation of Red Crescent society. Q Sci J Rescue Relief. 2014;6(3):20-30. [Persian]

34- Aliyari S, Zareian A, Hatami Z, Aliyari Shorehdeli M. Spiritual experiences and memories of healthcare personnel during the holy defense: a summative content analysis. J Mil Med. 2015;17(3):171-9. [Persian]

35- Bellamy RF. Death on the battlefield and the role of

1- Salamati P, Razavi SM, Shokraneh F, Mohazzab Torabi S, Laal M, Hadjati GH, et al. Mortality and injuries among Iranians in Iran-Iraq war: a systematic review. Arch Iran Med. 2013;16(9):542-50.

2- Mousavi B, Moradi-Lakeh M, Karbakhsh M, Soroush M. Years of life lost among Iranian people killed in the IraqIran war: the 25-year perspective. Int J Inj Contr Saf Promot. 2014;21(4):382-7.

3- Azarmi S, Farsi Z. Roy's adaptation model-guided education on promoting the adaptation of the veterans with lower extremities amputation. Iran Red Crescent Med. 2015;17(10):e25810.

4- Azarmi S, Farsi Z, Sajjadi SA. Development of adaptation questionnaire using Roy's adaptation model and its psychometrics on veterans with lower limb amputation. Hayat. 2014;19(4):26-37. [Persian]

5- Farsi Z, Azarmi S. Effect of Roy's adaptation modelguided education on coping strategies of the veterans with lower extremities amputation: a double -blind randomized controlled clinical trial. Int J Community Based Nurs Midwifery. 2016;4(2):127-36.

6- Farsi Z. Exploring coping strategies of healthcare providers with tension sources in Iran-Iraq war: a qualitative study. J Arch Mil Med. 2017;5(4):e59470.

7- Bazregar R, Khankeh HR, Ahmadi S, Hosseini MA, Rahgozar M, Moradian MJ. The evaluation of application of coordination based disaster response model in Rajaye Hospital disaster preparedness. Iranian J Nurs Res. 2013;8(29):10-18. [Persian]

8- Rahimaghaee F, Hatamopour K, Seylani K, Delfan V. Nurses' perceptions of care during wartime: a qualitative study. Int Nurs Rev. 2016;63(2):218-25.

9- Farsi Z, Dehghan Nayeri N. Pain and suffering: Experiences of health care professionals in the Iran- Iraq war-a content analysis study. J Mil Med. 2017;19(3):22233. [Persian]

10- Hagerty BM, Williams RA, Bingham M, Richard M. Military nurses and combat-wounded patients: a qualitative analysis of psychosocial care. Perspect Psychiatr Care. 2011;47(2):84-92.

11- Firouzkouhi MR, Kako M, Abdollahimohammad A, Zargham-Boroujeni A. Experiences of the civilian Iranian operating room nurses: a historical survey of the IranIraq war. J Nurs Midwifery Sci. 2016;3(1):31-41.

12- Gibbons SW, Hickling EJ, Watts DD. Combat stressors and posttraumatic stress in deployed military healthcare professionals: an integrative review. J Adv Nurs. 2012;68(1):3-21.

13- Soltani T, Baghianimoghadam MH, Ehrampoush MH, Baghian N, h Jafari A. Knowledge, attitude, and performance of nurses' crisis management in natural disasters in Yazd City. J Community Health Res. 2016;5(3):195-201. [Persian]

14- Amiri Jami H, Ahanchian M, Mahram B, Pakmehrd H. System of educational and qualification-based management about management models on the basis of competency: a meta-analysis. Procedia Soc Behav Sci. 2012;46:4751-5.

15- Firouzkouhi MR, Zargham-Boroujeni A, Nouraei M, Rahnama M, Babaeipour M. The effects of imposed war on Iran's nursing: a historical research. J Mil Med. 2015;17(3):127-36. [Persian]

16- Farsi Z. Professionalism of healthcare jobs in the war. J Arch Mil Med. 2017;5(1):e13210. 
38- Baker RR, Menard WS, Johns LA. The military nurse in Vietnam: stress and impact. J Clin Psychol. 1989;45(5):736-44.

39- Kaiser AP, Kabat DH, Spiro A, Davison EH, Stellman JM. Women at war: The crucible of Vietnam. SSM Popul Health. 2017;3:236-44.

40- Stander VA, Thomsen CJ. Sexual harassment and assault in the U.S. military: a review of policy and research trends. Mil Med. 2016;181(1 Suppl):20-7. first aid. Mil Med. 1987;152(12):634-5.

36- Mirhashemi S, Mirhashemi SAH, Ghanjal A, Mohebbi HA, Delavary AR, Saghafinia M, et al. Assessment of triage and transportation in Bam earthquake casualties whom were hospitalized in Baqiyatallah and some other Tehran Hospitals. J Mil Med. 2005;7(3):225-30. [Persian]

37- Agazio J. Army nursing practice challenges in humanitarian and wartime missions. Int J Nurs Pract. 2010;16(2):166-75. 